\title{
Genesis of the Zhijiadi Ag-Pb-Zn Deposit, Central North China Craton: Constraints from Fluid Inclusions and Stable Isotope Data
}

\author{
Tao Liu, ${ }^{1}$ Suo-Fei Xiong, ${ }^{1}$ Shao-Yong Jiang, ${ }^{1}$ Hua-Liang Li, ${ }^{2}$ \\ Qi-Zhi Chen, ${ }^{1}$ and Hai Jiang ${ }^{1}$ \\ ${ }^{1}$ State Key Laboratory of Geological Processes and Mineral Resources, \\ Faculty of Earth Resource, Collaborative Innovation Center for Exploration of Strategic Mineral Resources, \\ China University of Geosciences, Wuhan 430074, China \\ ${ }^{2}$ School of Earth Science, East China University of Technology, Nanchang 330013, China
}

Correspondence should be addressed to Suo-Fei Xiong; sophie_0913@foxmail.com and Shao-Yong Jiang; shyjiang@cug.edu.cn Received 24 June 2017; Accepted 11 September 2017; Published 19 October 2017

Academic Editor: Weidong Sun

Copyright (C) 2017 Tao Liu et al. This is an open access article distributed under the Creative Commons Attribution License, which permits unrestricted use, distribution, and reproduction in any medium, provided the original work is properly cited.

\begin{abstract}
The Zhijiadi Ag- $\mathrm{Pb}-\mathrm{Zn}$ deposit is located in the central North China Craton. Fluid inclusions (FIs) studies indicate three types of FIs, including aqueous, aqueous-carbonic, and daughter mineral-bearing multiphase inclusions. The daughter minerals in FIs are mainly composed of marcasite, chalcopyrite, calcite, and dolomite. Microthermometric data show that the homogenization temperature and salinity of FIs decrease gradually from early to late stages. Homogenization temperatures from early to main to late stages span from 244 to $334^{\circ} \mathrm{C}$, from 164 to $298^{\circ} \mathrm{C}$, and from 111 to $174^{\circ} \mathrm{C}$, respectively, while their salinities are $4.0-9.9 \mathrm{wt} . \%$ $\mathrm{NaCl}$ equiv., $0.5-12.7$ wt.\% $\mathrm{NaCl}$ equiv., and $0.2-8.8$ wt.\% $\mathrm{NaCl}$ equiv., respectively. Trapping pressures drop from 203-299 $\mathrm{MPa}$ (the early stage) to $32-158 \mathrm{MPa}$ (the main stage). The dropping of pressure and temperature and mixing and/or dilution of oreforming fluids result in the formation of ore deposit. Combined with $\mathrm{C}-\mathrm{O}-\mathrm{S}$ - $\mathrm{Pb}$ isotopic compositions, the initial ore-forming fluids and materials were likely derived from a magmatic system. As a whole, we proposed that this deposit belongs to medium-low temperature hydrothermal deposit related to volcanic and subvolcanic magmatism strictly controlled by the fault zones.
\end{abstract}

\section{Introduction}

The North China Craton (NCC), a major Precambrian craton in China, has been in focus in recent years with regard to craton destruction and the mechanism models [1-3]. There is consensus that the NCC was completed by the amalgamation of the western and eastern blocks bounded by the central zone named as the Trans-North China Orogen (TNCO) (Figure 1(a)) [2, 4-6]. Previous studies on ore deposits in the NCC are mainly focused along the margins of the craton, such as the Jiao-Liao gold province (eastern margin), Xiaoqinling gold province (southern margin), and Yan-Liao gold mineralization belt (northern margin) $[7,8]$. There are only few systematic investigations on the mineral deposits in the central NCC, especially for the Wutai-Hengshan terrain $[9,10]$. Most of the deposits in the Wutai-Hengshan region were related to Mesozoic magmatic-hydrothermal activity (e.g., [9]), and the types of deposits are primarily skarn, hydrothermal, and auriferous quartz vein deposit. The deposits discovered in the Wutai-Hengshan region include mainly $\mathrm{Au}, \mathrm{Cu}, \mathrm{Ag}, \mathrm{Pb}, \mathrm{Zn}$, and Mo deposits, including the Diaoquan $\mathrm{Ag}-\mathrm{Cu}$ deposit [10], the Zhijiadi Ag-Pb-Zn deposit [11], the Yixingzhai Au deposit [9], and the Boqiang $\mathrm{Cu}-\mathrm{Mo}$ deposit [12].

The Zhijiadi deposit is a large size $\mathrm{Ag}-\mathrm{Pb}-\mathrm{Zn}$ deposit with a proven reserve of $1100 \mathrm{t} \mathrm{Ag}$, and $50000 \mathrm{tPb}+\mathrm{Zn}$ [13], which is located in the central NCC. The occurrence of orebodies is mainly controlled by faults. Many researches have been carried out on the geology [11, 14-16], geochemistry [17, 18], and the source of metals $[14,19,20]$. However, the origin and evolution of ore-forming fluid of the Zhijiadi deposit are still ambiguous. Some previous studies show that the 


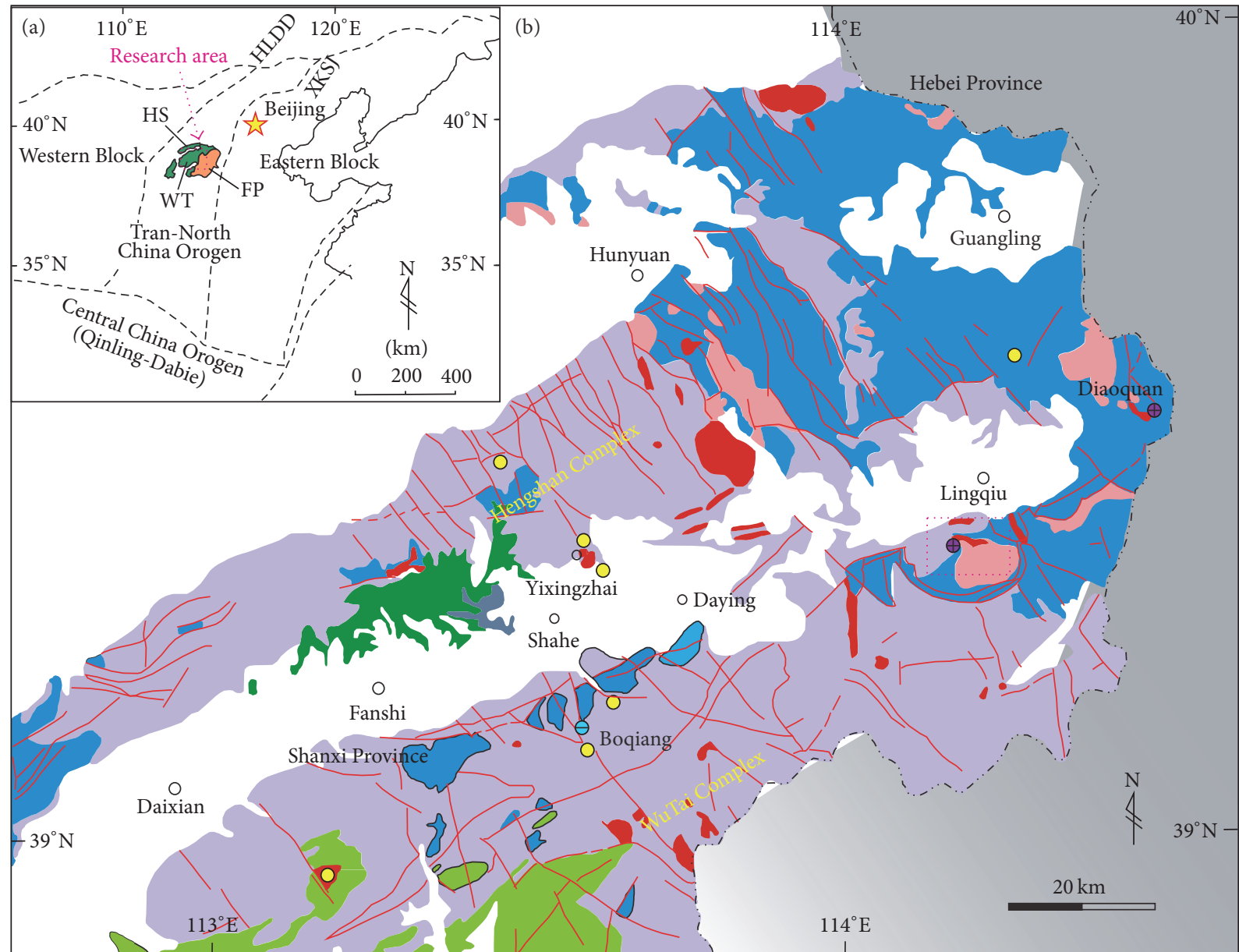

Archean + paleoproterozic metamorphic basement Paleoproterozoic metamorphic sedimentay rocks

Mesoproterozoic + paleozoic sedimentary rocks

Cenozoic basalt

Cenozoic sedimentary rocks

Mesozoic intrusive rocks

Mesozoic volcanic and minor sedimentary rocks

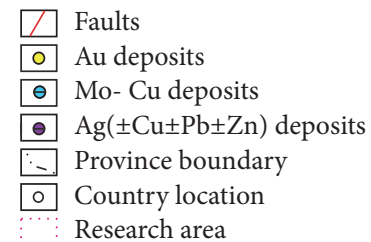

Figure 1: (a) Location of the study area in the central North China Craton (modified from [33]); (b) simplified tectonic map showing the distribution of metamorphic complexes in the Wutai-Hengshan region (modified from [12]). WT, Wutai Complex; FP, Fuping Complex; HS, Hengshan Complex; HLDD, Huashan-Lishi-Datong-Duolun Fault; XKSJ, Xinyang-Kaifeng-Shijiazhuang-Jianping Fault.

ore-forming fluids were with medium-low temperature and low salinity on the basis of microthermometric data from only the aqueous (W-type) fluid inclusions [14, 19, 21, 22]. Only Wang et al. [23] reported a few microthermometric data of $\mathrm{CO}_{2}$-bearing fluid inclusions (C-type) in the quartz veins, but the petrographic features of this type fluid inclusion are unclear. Fluid inclusions are the "fossils" of ore-forming fluid system, and only primary FIs can be used to determine the genesis of the original fluids and the metallogenic mechanism of ore deposits (e.g., [24]). The study of $\mathrm{CO}_{2}$ bearing fluid inclusions can provide an effective way to calculate the trapping pressure and to trace the ore-forming processes (e.g., [25]). There is no systematic petrographic and microthermometric data for the C-type FIs in the Zhijiadi deposit. In this study, we observed abundant $\mathrm{CO}_{2}$-bearing FIs and daughter mineral-bearing FIs in fluorite and sphalerite, and hence here we present a detailed fluid inclusion study from different minerals to find out the nature of the initial ore-forming fluids of the Zhijiadi deposit and to reconstruct the temperature-pressure condition for the mineralization. In addition, based on the geologic characteristics and isotopic compositions $(\mathrm{C}-\mathrm{O}-\mathrm{S}-\mathrm{Pb})$, we try to trace the ore material sources and to unravel the ore-forming conditions and ore genesis.

\section{Regional Geology}

The Wutai-Hengshan region is located at the central (NCC), to the west of the Taihang Mountains. The Precambrian basement rocks at this region from south to north are termed 
as the Fuping (FP) Complex, Wutai (WT) Complex, and Hengshan (HS) Complex, respectively (Figure 1(b)) [9]. The FP and HS Complexes are composed of 2.7-2.5 Ga amphibolite, granitic gneisses, mafic granulites, and metasedimentary rocks in granulite facies [26]. The WT Complex consists of Late Archean to Paleoproterozoic granitoid plutons, metamorphosed volcanic and sedimentary rocks (Figure 1(b)), which could be subdivided into three segments, namely, the lower, middle, and upper Wutai subgroups [27-29]. The lower part of the WT Complex is mainly composed of amphibolite facies peridotites, oceanic tholeiite, cherts, BIF (banded iron formation), sandstones, shales, calc-silicate rocks, siltstones, and minor limestones $[29,30]$. The middle part of the WT Complex contains felsic volcanic rocks and tholeiitic basalts which are metamorphosed to greenschist facies [30]. The upper part of the WT Complex mainly comprises quartz wackes, conglomerates, and mafic to intermediate and felsic volcanic rocks, metamorphosed into lower greenschist facies (Figure 1(b)). The WT Complex is considered to be unconformably overlain and also structurally interleaved by the Paleoproterozoic Huotuo Group metasedimentary rocks [29]. During Mesoproterozoic to Paleozoic era, the Wutai-Hengshan region also witnessed a prolonged stage of quiescence with deposition of sedimentary cover rocks on the metamorphic basement [12].

In this region, there are two intense stages of tectonic activities. The early stage NNW- and EW-trending faults are associated with Mesoarchean to Paleoproterozoic tectonism. The later stage is a series of NE- and NW-trending faults as a result of the compression of NW-SE trending horizontal stress in the Yanshan tectonic movements, which are associated with the Mesozoic magmatism and mineralization [31]. During the Late Jurassic to Early Cretaceous, the tectonic setting in this region changed from early compressional setting gradually into later extensional setting [32].

The magmatic activities are very extensive during Mesozoic. Mesozoic volcanic rocks are mainly distributed in the eastern part of the Wutai-Hengshan region, which are mainly composed of tuff, dacite, and rhyolite, accompanying a series of pyroclastic rocks. There are minor Proterozoic granite and diabase as dikes and Mesozoic intermediatefelsic hypabyssal rocks in the region. These intermediatefelsic hypabyssal rocks are mainly composed of quartz porphyry, granite porphyry, granite, felsite, granodiorite, quartz monzonite, and diorite porphyry. Widespread magmatic and tectonic activities also lead to hydrothermal mineralization and the formation of volcanic-sedimentary basins. Up to now, numerous $\mathrm{Au}, \mathrm{Ag}, \mathrm{Cu}, \mathrm{Pb}, \mathrm{Zn}$, and $\mathrm{Mo}$ ore deposits are mostly distributed in and around the intermediate-felsic hypabyssal rocks along the NW-trending faults. The timing of magmatism and metallogeny in the Wutai-Hengshan region is concentrated at $130-142 \mathrm{Ma}$ based on the LA-ICP-MS zircon $\mathrm{U}-\mathrm{Pb}$ ages (e.g., [12]).

\section{Deposit Geology}

The Zhijiadi deposit is located at the center of the WutaiHengshan region in the central NCC. The strata outcropped in the mining area are composed of basement and cover rocks (Figure 2(a)). The basement comprises the Paleoproterozoic metamorphic rocks of the Wutai Group that is mainly made up of gneiss, amphibolite, leptite, and mica quartz schist. The cover rocks in the area include Neoproterozoic carbonate rocks, Paleozoic carbonate, and clastic sedimentary rocks. Most of the area in the studied region is occupied by Later Jurassic pyroclastic rocks, and they could be subdivided into the Baiqi Formation and the Zhangjiakou Formation. The Baiqi Formation is composed of andesitic, dacitic, and tuffaceous breccia, while the Zhangjiakou Formation consists of volcanic suite including rhyolite, rhyolitic, and tuffaceous breccias.

Only a small number of the Paleoproterozoic granites and Early Cretaceous subvolcanic rocks are distributed in the northwest of the mining area. The Early Cretaceous subvolcanic rocks include quartz porphyry and granite porphyry with a small amount of sulfides disseminated in these rocks observed in the drill cores, such as sphalerite and galena. The quartz porphyry and granite porphyry show typical porphyritic texture. Plagioclase and quartz are the main phenocrysts in quartz porphyry, while K-feldspar and quartz occur as phenocrysts in granite porphyry. Pyrite, zircon, and apatite are the main accessory minerals in both of them. The quartz porphyry and granite porphyry yield LA-ICPMS zircon U-Pb ages of $135.4 \pm 1.3 \mathrm{Ma}$ and $132.1 \pm 1.8 \mathrm{Ma}$ (our unpublished data) and its geochemistry indicates that it belongs to the highly potassic and strongly peraluminous series [17].

The occurrence of orebodies in the Zhijiadi deposit is strictly controlled by a series of NW-, EW-, and NE-trending faults (Figure 2(b)). The $\mathrm{F}_{1}$ fault is an EW-trending tensionshear fault in the northern part of mining area, which inclines $62-80^{\circ}$ to southeast and extends up to $1800 \mathrm{~m}$. The $\mathrm{F}_{2}$ fault belongs to a NW-trending compression-shear fault, which is approximately 1300 meters long and 2-3 meters wide at the central part of the mining area, with the inclination of the southwest at an angle of $50-70^{\circ}$. The NNW-trending $\mathrm{F}_{3}$ fault is 1500 meters long and approximately 2 meters wide in the southwest side of the mining area. It is a tension-shear fault and dips at $50-70^{\circ}$ toward the southwest. Among these faults, the $\mathrm{F}_{2}$ fault is the most important ore-controlling structure (Figure 3), along which abundant hydrothermal breccias and cataclastic rocks are well developed (Figure 3(a)). In plain view, the hydrothermal breccia has a spindle or elliptical shape with long axes of approximately $600 \mathrm{~m}$ and vertical length of less than $200 \mathrm{~m}$ [11]. The breccia fragments are composed of quartz porphyry, tuff, and dacite, with weak chloritization.

Twelve orebodies have been identified in the mining area. Most of orebodies are restricted to distribution along the $\mathrm{F}_{2}$ fault zone, and their thickness varies from 1 to $80 \mathrm{~m}$ along the northeastern direction with an average thickness at $8 \mathrm{~m}$ (Figure 3(b)). The largest orebody (number (1)) expands more than $1000 \mathrm{~m}$ in length and $0.5-10 \mathrm{~m}$ width, and the average grades of which are $270 \mathrm{~g} / \mathrm{t} \mathrm{Ag}, 1.2 \% \mathrm{~Pb}$, and $1.7 \% \mathrm{Zn}$ [15]. Recent exploration survey shows that the orebodies do not pinch in the controlled depth, suggesting this deposit has great potential for further exploration at depth [13]. 


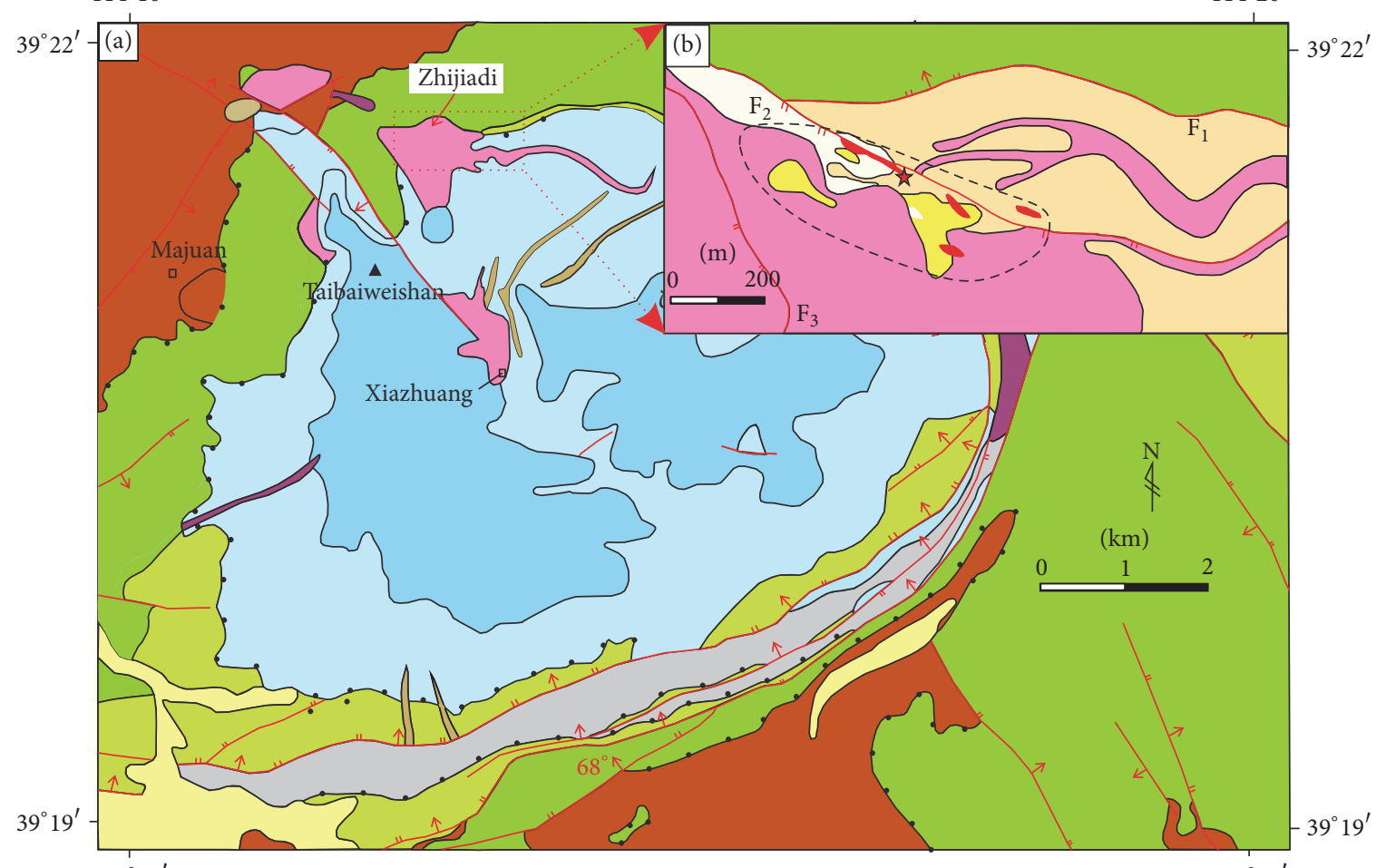

$114^{\circ} 10^{\prime}$

$114^{\circ} 20^{\prime}$

\begin{tabular}{l}
\hline Quaternary sediment \\
Volcanic breccia \\
Tuff breccia \\
\hline \hline Quartz porphyry breccia \\
Early Cretaceous quartz porphyry \\
Early Cretaceous granite porphyry \\
Dacite \\
\hline$\square$ Paleoproterozoic granite \\
\hline$\square$ Later juarassic rhyolite and rhyolitic breccia \\
\hline$-D a t e r$ juarassic andesitic and dacitic breccia
\end{tabular}

\begin{tabular}{l}
$\square$ Later juarassic conglomerate \\
Paleozoic sedimentary rocks \\
Neoproterozoic metamorphic sedimentary rocks \\
Archaeozoic metamorphic rocks \\
Fault \\
\hline \hline Sedimentary unconformity \\
\hline$\square$ Hydrothermal breccia \\
\hline \hline O Orebody and number \\
\hline$\star$ Sample location
\end{tabular}

FIGURE 2: (a) Simplified geologic map (modified from unpublished internal map of the third geological exploration institute of China Metallurgical Geology Bureau). (b) The distribution of orebodies in the Zhijiadi deposit (modified from [14]).

The breccia- and vein-type ores in the Zhijiadi deposit are the main ore types with multiple Ag-bearing sulfides (Figures $4(\mathrm{a})$ and $4(\mathrm{~b})$ ). The main silver-bearing minerals include nature silver (Figure 4(c)), argentite, and acanthite, and minor freibergite and sternbergite are also reported [13]. Other sulfides are dominated by pyrite, galena, sphalerite, and chalcopyrite (Figures $4(\mathrm{~d})-4(\mathrm{f})$ ). The gangue minerals are quartz, rhodochrosite, fluorite, calcite, and dolomite (Figures $4(\mathrm{f})-4(\mathrm{~h}))$. Most ores occur as stockwork and vein, but veinlet-disseminated and brecciated varieties are also present. The pyrite is locally present as euhedral-subhedral granule and replaced by the galena and sphalerite (Figures 4(i) and $4(\mathrm{j})$ ). The chalcopyrite commonly occurs within sphalerite as exsolution (Figure 4(h)). Argentite and acanthite can be identified for intergrowth with galena (Figure $4(\mathrm{k})$ ). Corrugation structure is also observed in galena, which may be caused by the stress effect (Figure 4(1)).

The hydrothermal alterations associated with $\mathrm{Ag}-\mathrm{Pb}$ $\mathrm{Zn}$ mineralization in the Zhijiadi deposit mainly include silicification, carbonation, sericitization, and chloritization. On the basis of mineral assemblages and the cross-cutting relationship, the mineralization process at Zhijiadi deposit can be divided into primary hydrothermal stages and a supergene epoch (Figure 5). The primary hydrothermal stages could be subdivided into three stages, namely, (1) the early stage characterized by the assemblages of quartz + pyrite veins (Figure 6(a)), (2) the main ore stage characterized by galena + sphalerite + chalcopyrite + fluorite + rhodochrosite + multiple Ag-bearing sulfides (Figures 6(b)-6(e)), and (3) the late stage characterized by quartz + calcite + dolomite veins (Figure 6(f)).

\section{Analytical Methods}

4.1. Fluid Inclusion Studies. Samples were collected from the orebodies in level 1320 around $F_{2}$ fault zone in the Zhijiadi deposit. Thirty-seven double-polished thin sections (about $200 \mu \mathrm{m}$ thick) associated with three hydrothermal 


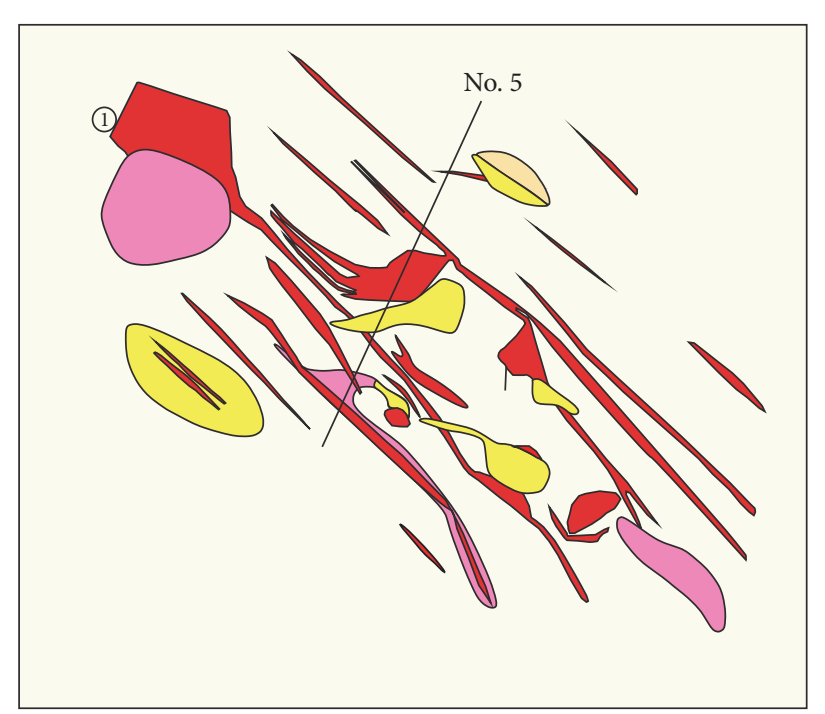

Volcanic breccia

Tuff breccia

Quartz porphyry breccia

Quartz porphyry

Orebody and number

$\mathrm{F}_{2}$ fault

Prospection line Number 5

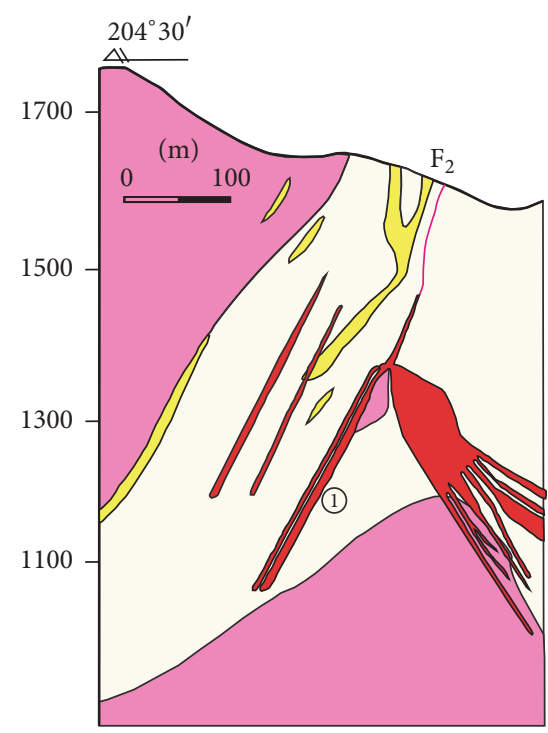

)

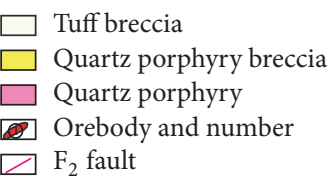

(b)

FIGURE 3: (a) Simplified level plan 1320 (modified from [13]); (b) geological cross section of number 5 exploration of the Zhijiadi deposit (modified from [17]).

stages were examined under transmitted light to identify the phase, shape, size, and distribution. Eighteen of doublepolished thin sections were selected for microthermometric measurements and laser Raman spectroscopic analyses.

Fluid inclusion petrographic studies were carried out in National Demonstration Center for Experimental Mineral Exploration Education, China University of Geosciences, Wuhan. Microthermometric measurements were conducted by a Linkam THMSG 600 heating-freezing stage (from -196 to $550^{\circ} \mathrm{C}$ ) mounted on a Leica DM2700P microscope at the China University of Geosciences, Wuhan. The heatingfreezing stages calibration is carried out at $-56.6^{\circ} \mathrm{C}, 0.0^{\circ} \mathrm{C}$, and $374.1^{\circ} \mathrm{C}$ using the standard of synthetic FIs supplied by FLUID INC, USA. During heating/freezing runs, the heating/freezing rate was generally constrained at $0.2-5^{\circ} \mathrm{C} / \mathrm{min}$ but was reduced to $<0.2^{\circ} \mathrm{C} / \mathrm{min}$ near the phase transformation. The estimated accuracies of the heating and freezing measurements were $\pm 0.5^{\circ} \mathrm{C}, \pm 0.2^{\circ} \mathrm{C}$, and $\pm 2^{\circ} \mathrm{C}$ for runs in the range of $-120^{\circ} \mathrm{C}$ to $-70^{\circ} \mathrm{C},-70^{\circ} \mathrm{C}$ to $+100^{\circ} \mathrm{C}$, and $+100^{\circ} \mathrm{C}$ to $+600^{\circ} \mathrm{C}$, respectively. Ice-melting temperatures were obtained at a heating rate of less than $0.1^{\circ} \mathrm{C} / \mathrm{min}$ and homogenization temperatures at a rate of $\leq 1^{\circ} \mathrm{C} / \mathrm{min}$. Salinities were calculated using the equation of Hall et al. [40] for aqueous inclusions and of Roedder [41] for aqueouscarbonic inclusions. Densities $\left(\mathrm{g} / \mathrm{cm}^{3}\right)$ and pressures were estimated using the Flincor software package according to microthermometric data for $\mathrm{H}_{2} \mathrm{O}-\mathrm{NaCl}-\mathrm{CO}_{2}$ system [42].

Laser Raman spectroscopic analyses of FIs were carried out at the State Key Laboratory of Geological Processes and
Mineral Resources, China University of Geosciences, Wuhan. The analyses were conducted with a DXR laser Raman spectrometer manufactured by the Thermo Fisher Scientific Company, using a $514.5 \mathrm{~nm} \mathrm{Ar}{ }^{+}$ion laser as the excitation source operating at $20 \mathrm{~mW}$. The exposure time was $20-40 \mathrm{~s}$ and ranged from 50 to $3500 \mathrm{~cm}^{-1}$. Spectrograph aperture was defined as $50 \mu \mathrm{m}$ pinhole. Instrumental settings were kept constant during all analyses.

4.2. Carbon and Oxygen Isotope Analyses. Rhodochrosite generally coexists with fluorite and sphalerite in the main stage (Figure 4). Eight samples are collected from the orebodies in level 1320. Carbon and oxygen isotope analyses were conducted at Key Laboratory of Tectonics and Petroleum Resources, China University of Geosciences, Wuhan. The carbon and oxygen isotopic compositions were measured as follows: dry samples were powdered and reacted overnight with $100 \%$ phosphoric acid at $72^{\circ} \mathrm{C}$ to extract $\mathrm{CO}_{2}$. The trapped $\mathrm{CO}_{2}$ was purified and analyzed on a MAT-253 isotope ratio mass spectrometer for the carbon and oxygen isotopic compositions. Isotopic values are reported to Vienna Pee Dee Belemnite standard (V-PDB), but oxygen isotopes have been converted to V-SMOW standard, using the formula $\delta^{18} \mathrm{O}_{\mathrm{V} \text {-SMOW }}=1.03086 \times \delta^{18} \mathrm{O}_{\mathrm{V} \text {-PDB }}+30.86$ [43].

4.3. Sulfur Isotope Analysis. Thirteen standard polished sections (one pyrite-bearing quartz porphyry sample and 12 ore samples) are collected to carry out in situ sulfur isotope 


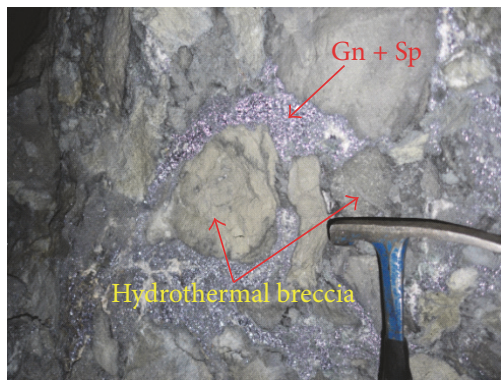

(a)

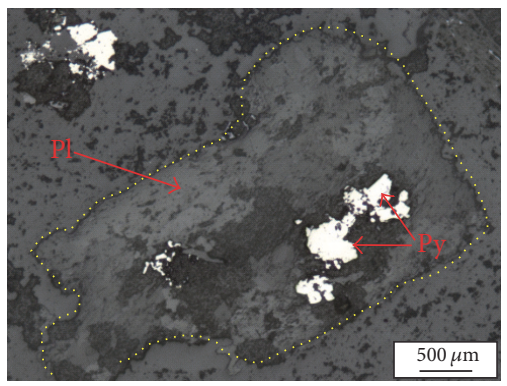

(d)

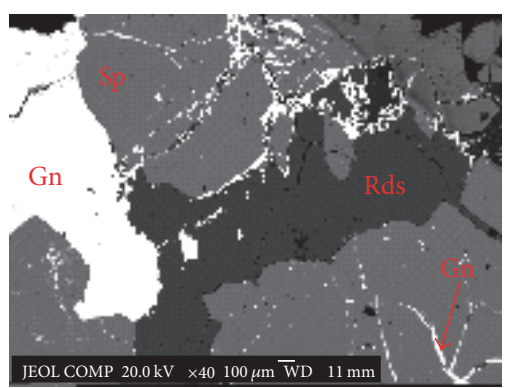

(g)

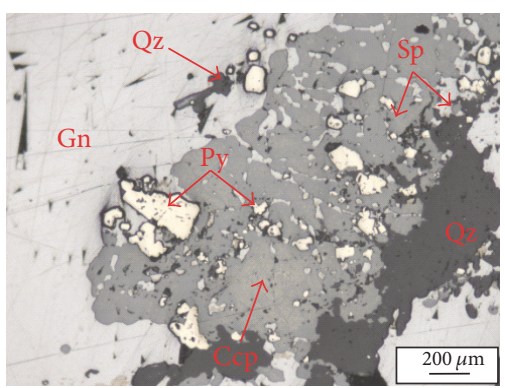

(j)

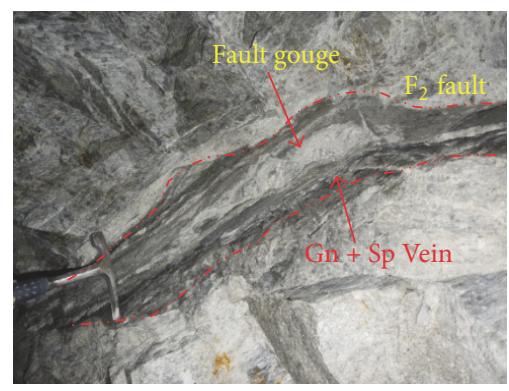

(b)

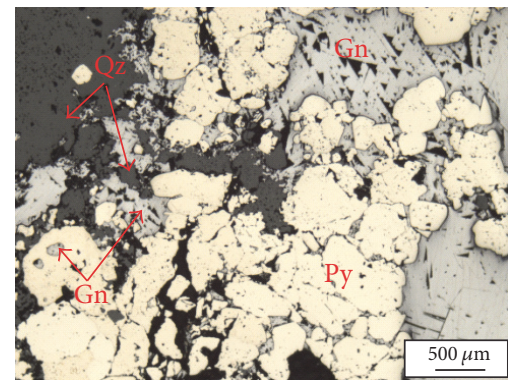

(e)

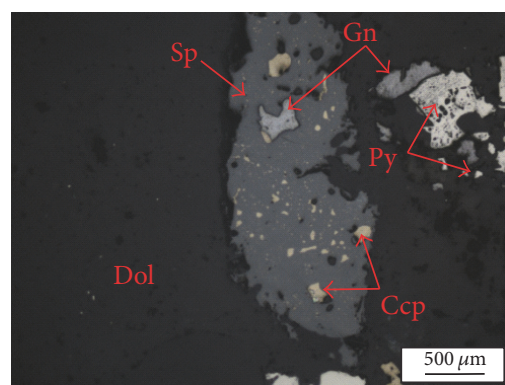

(h)

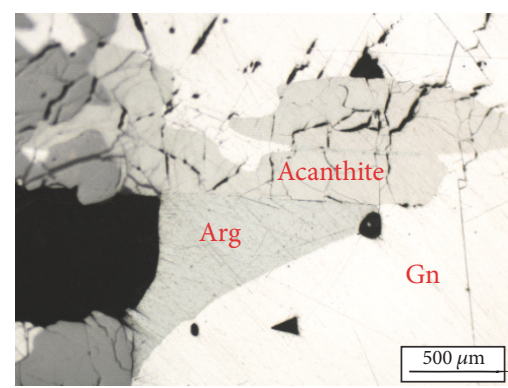

$(\mathrm{k})$

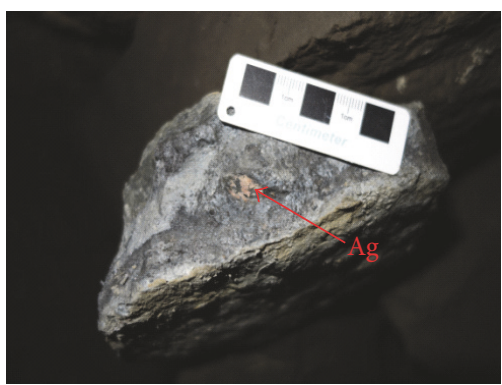

(c)

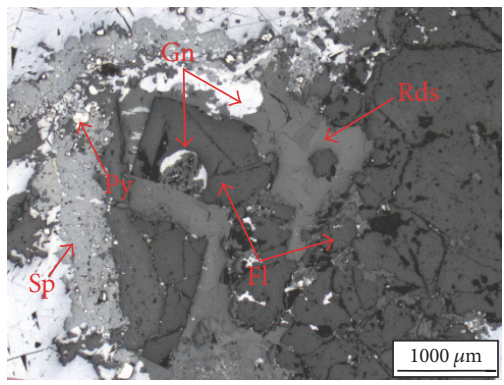

(f)

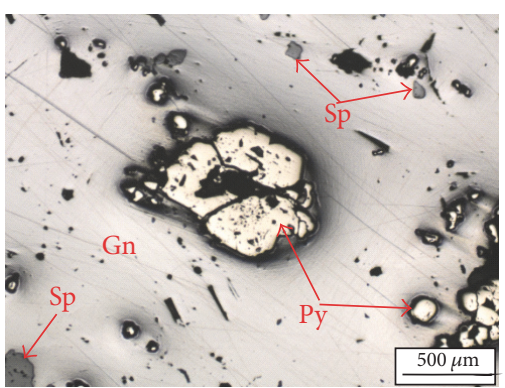

(i)

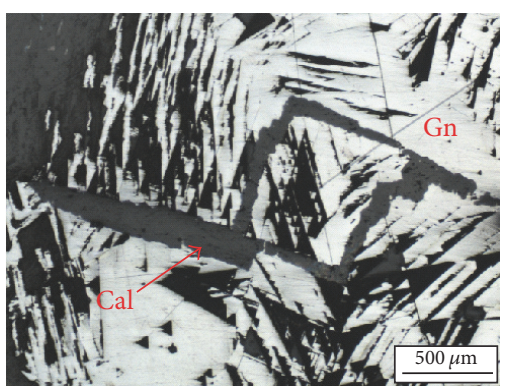

(1)

FIGURE 4: Photographs of hand specimens, photomicrographs, and back-scatter election (BSE) images showing ore fabrics and mineral assemblages of the Zhijiadi deposit. (a) Galena and sphalerite filling in hydrothermal breccia. (b) Galena and sphalerite occurring as vein in near $\mathrm{F}_{2}$ fault zone. (c) Native silver in the gangue minerals. (d) Pyrite disseminated in plagioclase phenocryst of quartz porphyry. (e) The early stage quartz and pyrite replaced by galena. (f) Euhedral-subhedral fluorite replaced by rhodochrosite. (g) Coexistence of sphalerite and rhodochrosite in the main stage and replaced by galena (BSE). (h) Chalcopyrite as emulsion droplet within sphalerite, making an exsolution texture. (i) Euhedral-subhedral pyrite replaced by galena. (j) Galena intergrowth with sphalerite in the main stage. (k) Argentite and acanthite intergrow with galena. (1) Corrugation structure in galena caused by the stress effect. Py, pyrite; Gn, galena; Sp, sphalerite; Ccp, chalcopyrite; Arg, argentite; Qz, quartz; Rds, rhodochrosite; Fl, fluorite; Cal, calcite; Pl, plagioclase; Dol, dolomite. 


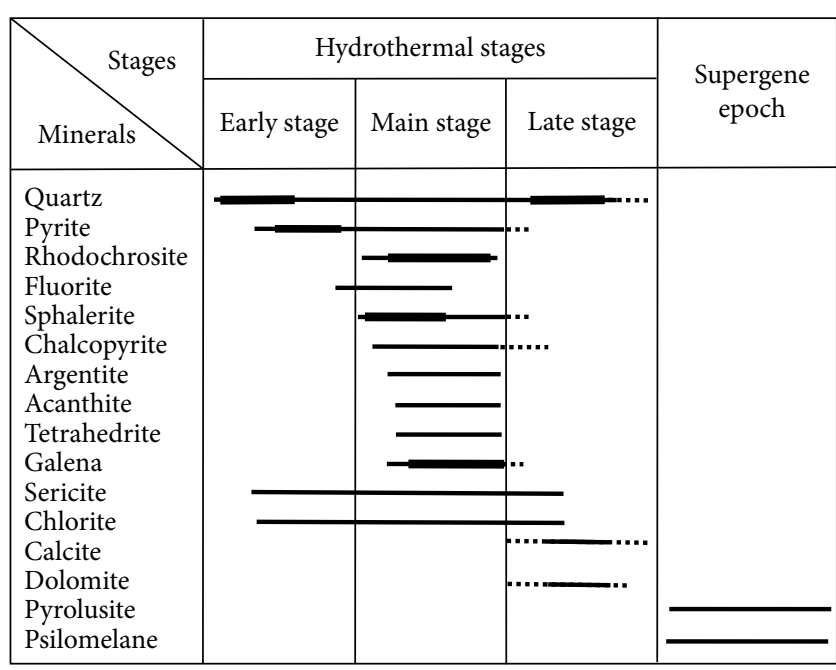

FIGURE 5: Paragenetic sequence of minerals in the Zhijiadi deposit.

analyses. Minerals include pyrite, sphalerite, galena, and sphalerite covering the early and main stages.

In situ sulfur isotope analyses on sulfides were conducted by the Nu Plasma II MC-ICP-MS equipped with the Resonetics-S155 excimer ArF laser ablation system at the State Key Laboratory of Geological Processes and Mineral Resources, China University of Geosciences, Wuhan. The diameter of laser beam was set to $33 \mu \mathrm{m}$ with a laser repetition rate of $10 \mathrm{~Hz}$, and the ablation process was set to last for $40 \mathrm{~s}$. High-purity helium gas, mixing with Ar gas and a small amount of $\mathrm{N}_{2}$ gas, was used to transport the ablated materials into the mass spectrometer. Standard-sample bracket method was used to determine the $\delta^{34} \mathrm{~S}$ values of samples throughout the whole MC-ICP-MS analytical process. The true sulfur isotope ratio was calculated by the correction for instrumental mass bias by linear interpolation between the biases calculated from two neighboring standard-sample analyses. The primary standards used in this study were NBS123 for sphalerite and WS-1 (in-house standard) for pyrite, galena, and chalcopyrite. The $\delta^{34} S_{\mathrm{V} \text {-CDT }}$ value for NBS-123 is recommended to be $17.0 \%$ [ [44], and the $\delta^{34} \mathrm{~S}_{\mathrm{V}-\mathrm{CDT}}$ values for WS-1 natural pyrite were determined to be $0.9 \%$ o through the isotope ratio mass spectrometer, as well as $1.1 \pm 0.2 \%$ by SIMS at the Chinese Academy of Geochemistry, Guangzhou [45]. The $\delta^{34} \mathrm{~S}_{\mathrm{V}-\mathrm{CDT}}$ value of NBS-123 calibrated through the WS-1 is $17.0 \pm 0.5 \%$, which indicated that the matrix effect of different sulfides is not obvious. The sulfur isotopic data are reported in delta notation (\%o) relative to Vienna Canyon Diablo Troilite (V-CDT). The analytical precision $(1 \sigma)$ was about \pm 0.1 per mil and detailed analytical conditions and procedures can be seen in $[45,46]$.

4.4. Lead Isotope Analysis. The lead isotopic compositions of four sphalerite, ten galena samples, and four quartz porphyry samples have been analyzed on a Neptune Plus MC-ICP-MS at State Key Laboratory for Mineral Deposits Research, Nanjing University. Sulfide samples were completely dissolved by $\mathrm{HNO}_{3}$ and purified by cation-exchange resin. The standard errors of data were calculated by the software of Neptune through analyses of 40 data types ( 4 blocks, 10 cycles). In $200 \mathrm{ppb} \mathrm{Pb}$ solution, the signal intensity of ${ }^{208} \mathrm{~Pb}=6 \mathrm{~V}$, whereas in the blank solution ${ }^{208} \mathrm{~Pb}=20 \mathrm{mv}$. Tl NBS997 $\left({ }^{203} \mathrm{Tl} /{ }^{205} \mathrm{Tl}=0.418922\right)$ is added to sample solution for correcting mass bias of $\mathrm{Pb}$ isotope ratios, with analytical reproducibility of $0.1 \%(2 \sigma)$ for ${ }^{206} \mathrm{~Pb} /{ }^{204} \mathrm{~Pb},{ }^{207} \mathrm{~Pb} /{ }^{204} \mathrm{~Pb}$, and $0.2 \%(2 \sigma)$ for ${ }^{208} \mathrm{~Pb} /{ }^{204} \mathrm{~Pb}$, and detailed analytical conditions and procedures can be seen in [47].

4.5. Electron Probe Microanalyses (EPMA) of Sulfides. Mineral compositions were determined at the State Key Laboratory of Geological Processes and Mineral Resources, China University of Geosciences, Wuhan, with a JEOL JXA-8100 Electron Probe Microanalyzer equipped with four wavelength-dispersive spectrometers (WDS). The samples were firstly coated with a thin conductive carbon film prior to analysis. The precautions suggested by [48] were used to minimize the difference of carbon film thickness between samples and obtain a ca. $20 \mathrm{~nm}$ approximately uniform coating. During the analysis, an accelerating voltage of $20 \mathrm{kV}$, a beam current of $20 \mathrm{nA}$, and a $2 \mu \mathrm{m}$ spot size were used to analyze minerals. Data were corrected online using a modified ZAF (atomic number, absorption, and fluorescence) correction procedure. The peak counting time was $10 \mathrm{~s}$ for $\mathrm{S}, \mathrm{Fe}, \mathrm{Cd}, \mathrm{Cu}$, $\mathrm{Pb}$, and $\mathrm{Zn}$ and $20 \mathrm{~s}$ for $\mathrm{Ge}$ and $\mathrm{Ga}$. The background counting time was one-half of the peak counting time on the high- and low-energy background positions. The following standards were used: germanium $(\mathrm{Ge})$, galena $(\mathrm{S})$, pyrite $(\mathrm{Fe})$, gallium arsenide $(\mathrm{Ga})$, cadmium $(\mathrm{Cd})$, copper $(\mathrm{Cu})$, galena $(\mathrm{Pb})$, and zinc $(\mathrm{Zn})$. The minimum hydrothermal fluid temperatures were calculated by using the correlation of the $\mathrm{Fe} / \mathrm{Zn}$ ratios in the linear equation [49].

\section{Results}

5.1. Type and Occurrence of Fluid Inclusions. Petrographic study of fluid inclusion was conducted with optical microscope. All samples contain abundant primary and pseudosecondary inclusions with ovoid, elliptical, irregular, and negative crystal shapes. In general, the primary FIs were identified by their occurrence in crystal growth zones of the host mineral or as the isolated inclusions (Figure 7(a)), while secondary FIs present as penetrating crystal boundaries (Figures $7(\mathrm{a})$ and $7(\mathrm{~b})$ ). These FIs vary from $4 \mu \mathrm{m}$ to over $60 \mu \mathrm{m}$; most of them are $5 \mu \mathrm{m}$ to $30 \mu \mathrm{m}$ in size. On the basis of phase proportion at room temperature $\left(25^{\circ} \mathrm{C}\right)$ and compositional components, three types of fluid inclusions were identified from quartz, rhodochrosite, fluorite, and sphalerite, as follows:

(1) W-type: primary aqueous (W-type) inclusions consist of two phases (liquid phase and vapour phase) (Figures $7(\mathrm{c})-7(\mathrm{e})$ ). They are the most common type, which occupy $60 \%$ of the total primary FIs in different stages and minerals (Figures 7(c)-7(e)). They vary from negative crystal to irregular shapes. The 


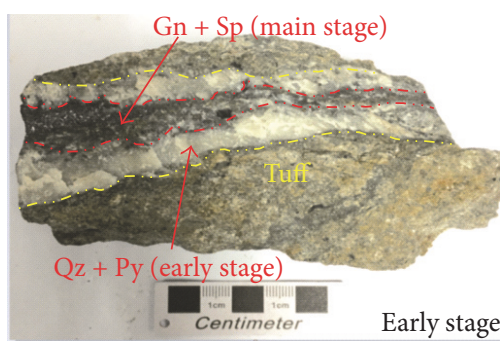

(a)

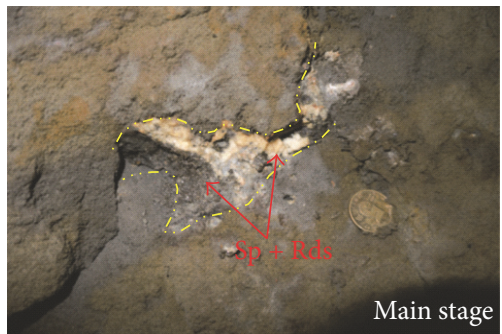

(d)

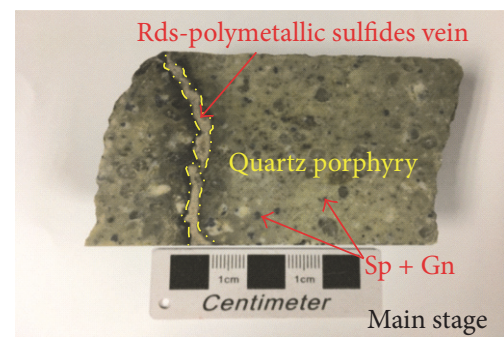

(b)

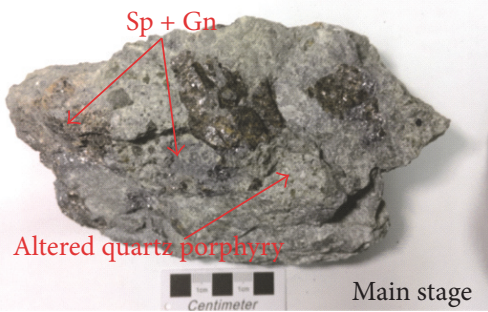

(e)

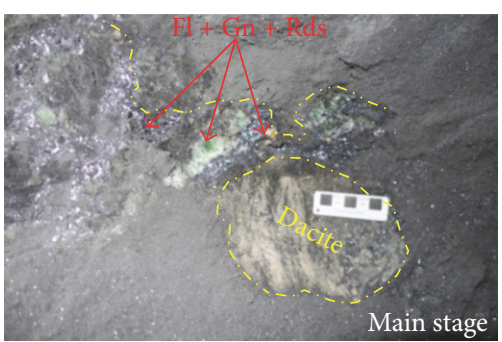

(c)

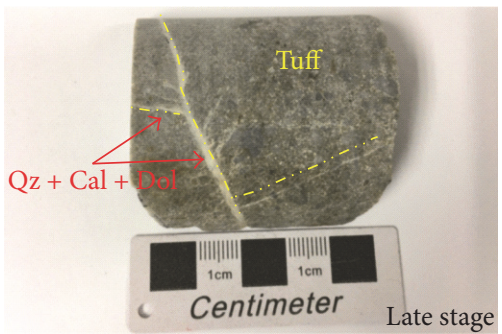

(f)

FIgURE 6: Photomicrographs showing three stages in the Zhijiadi deposit. (a) The early stage quartz-pyrite vein. (b) The main stage rhodochrosite polymetallic sulfides vein cross-cutting quartz porphyry and some sphalerite and galena disseminated in quartz porphyry. (c) The main stage fluorite-galena filling in the dacite breccia. (d) Coexistence of sphalerite and rhodochrosite in the hydrothermal breccia. (e) Brecciated sphalerite distributing in the altered quartz porphyry breccia. (f) The late stage quartz-carbonate vein cross-cutting the tuffaceous breccia. Py, pyrite; Gn, galena; Sp, sphalerite; Rds, rhodochrosite; Fl, fluorite; Cal, calcite; Dol, dolomite.

diameter of them range from 4 to $20 \mu \mathrm{m}$, and their vapour volume spans from 5 to 45 percent.

(2) C-type: primary carbonic-aqueous (C-type) inclusions contain two (vapour $\mathrm{CO}_{2}+$ liquid $\mathrm{CO}_{2}$ ) or three phases (vapour $\mathrm{CO}_{2}+$ liquid $\mathrm{CO}_{2}+$ liquid $\mathrm{H}_{2} \mathrm{O}$ ), which occupy $30 \%$ of the total primary FIs. These fluid inclusions were identified in both early and main stages. They are mainly observed in quartz, fluorite, and sphalerite (Figures $7(\mathrm{f})-7(\mathrm{~h})$ ). These FIs are mostly $5-30 \mu \mathrm{m}$ in size, showing ovoid, elliptical, irregular, and negative shapes. Their $\mathrm{CO}_{2}$ volumetric proportions at room temperature vary from 5 to $30 \%$. Different from the C-type FIs in the quartz and sphalerite, the C-type FIs in fluorite grains commonly coexist with the $\mathrm{CO}_{2}$-bearing S-type (daughter minerals are calcite and dolomite) inclusions and $\mathrm{W}$-type inclusions.

(3) S-type: daughter mineral-bearing multiphase inclusions consist of vapour, liquid, and solid phase, accounting for $10 \%$ of the total primary FIs. Abundant transparent minerals-bearing S-type FIs are mostly distributed in the main stage fluorite and sphalerite, while some opaque mineral-bearing S-type FIs mainly occur in the early stage quartz and the main stage sphalerite. They are oval, polygonal, irregular, and negative crystals, and their diameter fluctuates in a wide range from 4 to $60 \mu \mathrm{m}$. Daughter minerals in S-type FIs include transparent minerals and opaque minerals. Transparent daughter minerals are calcite and dolomite (Figures 7(i) and 7(j)), while opaque daughter minerals are composed of marcasite and chalcopyrite (Figures $7(\mathrm{k})$ and $7(\mathrm{l})$ ).

5.2. Laser Raman Spectroscopy. Laser Raman spectroscopy analyses were carried out to constrain the fluid inclusion compositions of representative samples from three different hydrothermal stages, and the results are shown in Figure 8. The results show that the vapour phase of aqueous-carbonic inclusions in the early stage quartz grains was confirmed as $\mathrm{CO}_{2}$ by the peak of 1281 and $1385 \mathrm{~cm}^{-1}$ (Figure $8(\mathrm{a})$ ). The gas phase of two-phase fluid inclusions in the main stage rhodochrosite contains minor $\mathrm{CO}_{2}$ with the peak of 1283 and $1386 \mathrm{~cm}^{-1}$ (Figure 8(b)). The main stage fluorite and sphalerite also contain abundant $\mathrm{CO}_{2}$ in the vapour phase of C-type FIs, as indicated by the peak of 1280 and $1384 \mathrm{~cm}^{-1}$ and 1282 and $1384 \mathrm{~cm}^{-1}$, respectively (Figures $8(\mathrm{c})$ and $8(\mathrm{~d})$ ). Transparent daughter minerals in S-type FIs of the main stage fluorite and sphalerite are calcite and/or dolomite at the peaks of $1081 \mathrm{~cm}^{-1}$ and $1098 \mathrm{~cm}^{-1}$, respectively (Figures $8(\mathrm{e})$ and $8(\mathrm{f}))$. Opaque daughter minerals in the early stage quartz are marcasite, which are indicated by the peak of $339 \mathrm{~cm}^{-1}$ (Figure $8(\mathrm{~g})$ ). The $289 \mathrm{~cm}^{-1}$ peak demonstrates that some opaque daughter minerals in the main stage sphalerite are chalcopyrite (Figure $8(\mathrm{~h})$ ).

5.3. Microthermometry. All the C-type and W-type consistently homogenize into liquid phase. The microthermometric results, calculated salinities and densities of W-type and C-type of the early, main, and late stages, are shown in Table 1 and Figures 9 and 10. When these S-type FIs were 


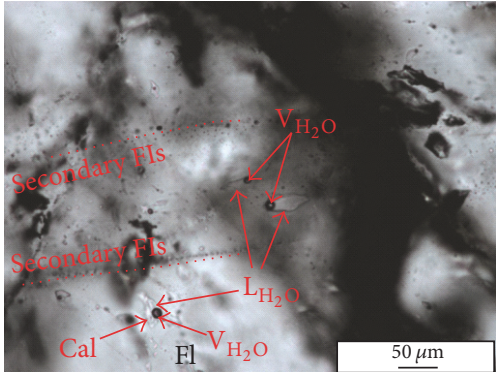

(a)

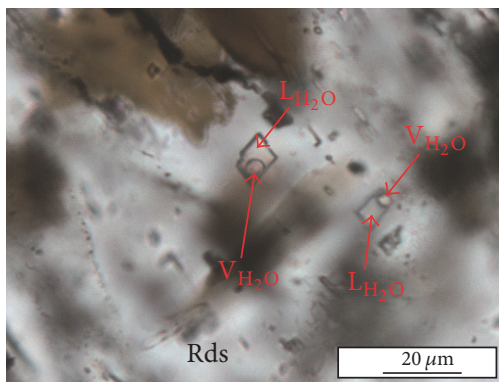

(d)

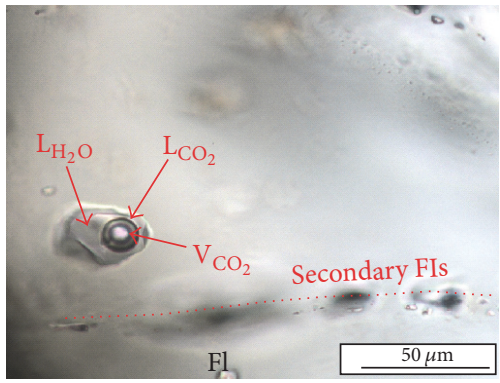

(g)

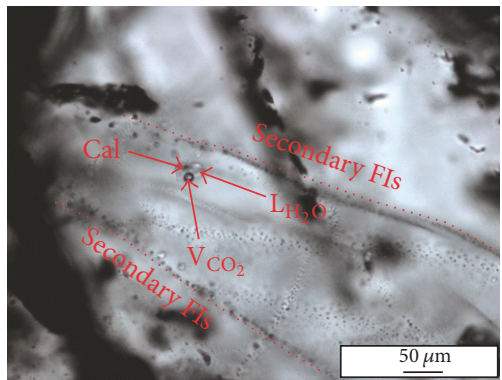

(j)

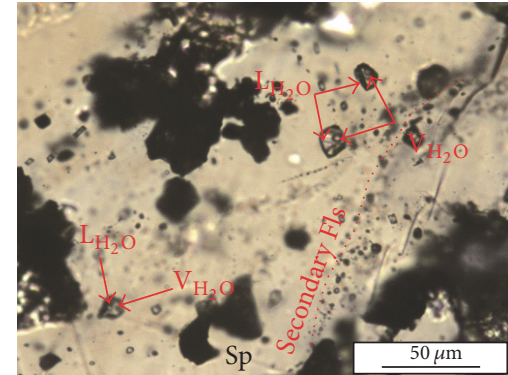

(b)

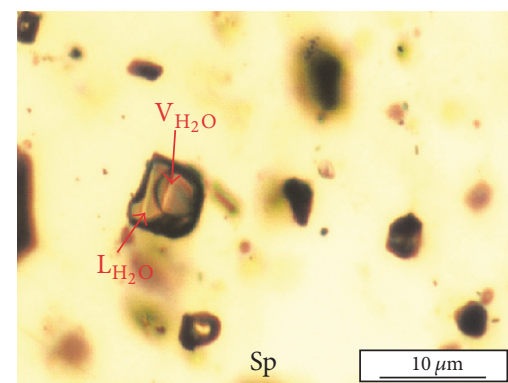

(e)

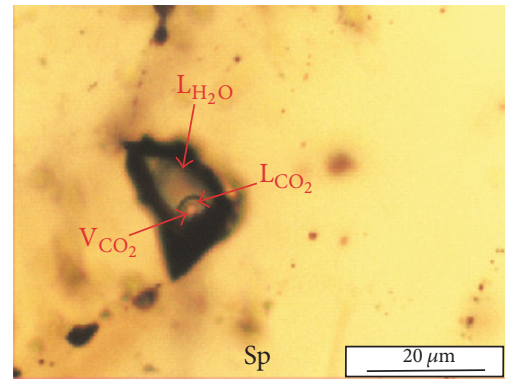

(h)

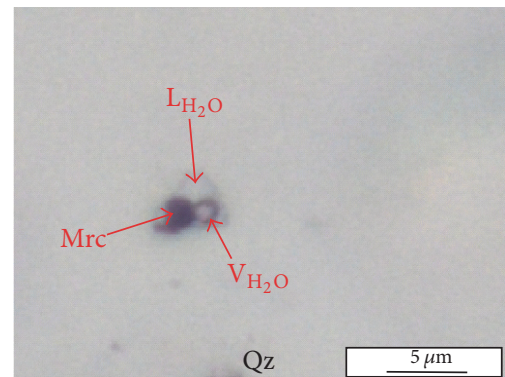

$(\mathrm{k})$

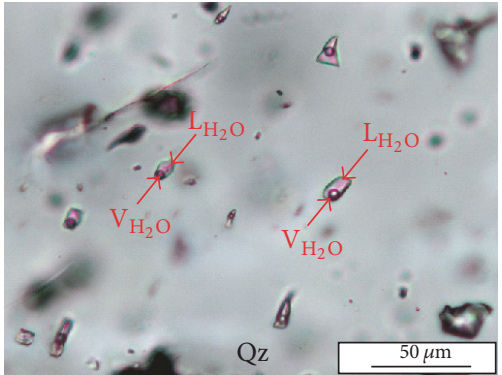

(c)

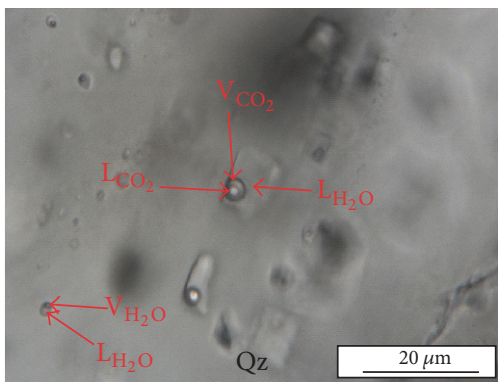

(f)

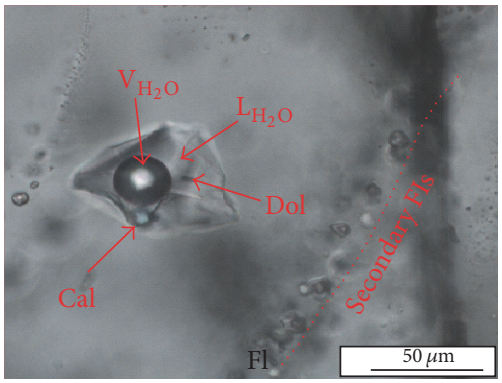

(i)

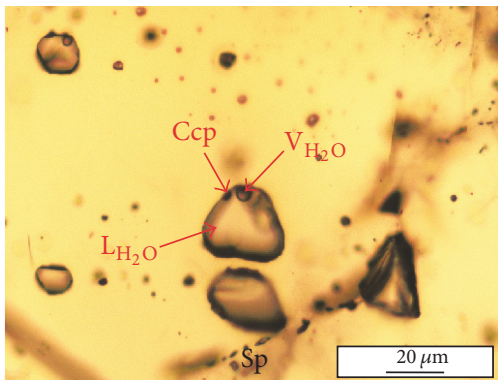

(l)

Figure 7: Photomicrographs showing the types and distribution of fluid inclusions observed in the Zhijiadi deposit. (a) Primary aqueous (W-type) inclusions coexisting with daughter mineral-bearing (S-type) inclusions in the main stage fluorite and these secondary W-type inclusions in a linear distribution penetrating crystal boundaries of fluorite. (b) Cluster of primary W-type inclusions in the main stage sphalerite and these secondary W-type inclusions penetrating crystal boundaries of sphalerite. (c) W-type inclusions clustered in the early stage quartz. (d) Primary W-type inclusions clustered in the main stage rhodochrosite. (e) Isolation of W-type inclusions from the main stage sphalerite. (f) Coexistence of aqueous-carbonic (C-type) inclusions and W-type inclusions in the early stage quartz crystals; C-type inclusions in the main stage fluorite (g) and sphalerite (h); (i) S-type inclusions in main stage fluorite (daughter minerals including calcite and dolomite), showing an obvious difference from the secondary W-type inclusions; (j) calcite-bearing S-type inclusions with $\mathrm{CO}_{2}$ vapour bubble in the main stage fluorite; $(\mathrm{k})$ marcasite-bearing S-type inclusions in the early stage quartz; (l) chalcopyrite-bearing S-type inclusions in the main stage sphalerite. $\mathrm{V}_{\mathrm{CO} 2}$, vapour $\mathrm{CO}_{2} ; \mathrm{L}_{\mathrm{CO} 2}$, liquid $\mathrm{CO}_{2} ; \mathrm{V}_{\mathrm{H} 2 \mathrm{O}}$, vapour $\mathrm{H}_{2} \mathrm{O} ; \mathrm{L}_{\mathrm{H} 2 \mathrm{O}}$, liquid $\mathrm{H}_{2} \mathrm{O} ; \mathrm{Qz}$, quartz; Rds, rhodochrosite; Fl, fluorite; Sp, sphalerite; Cal, calcite; Dol, dolomite; Mrc, marcasite. 


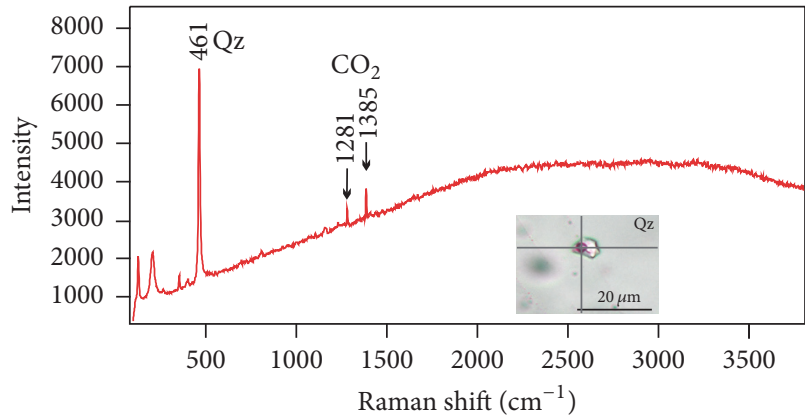

(a)

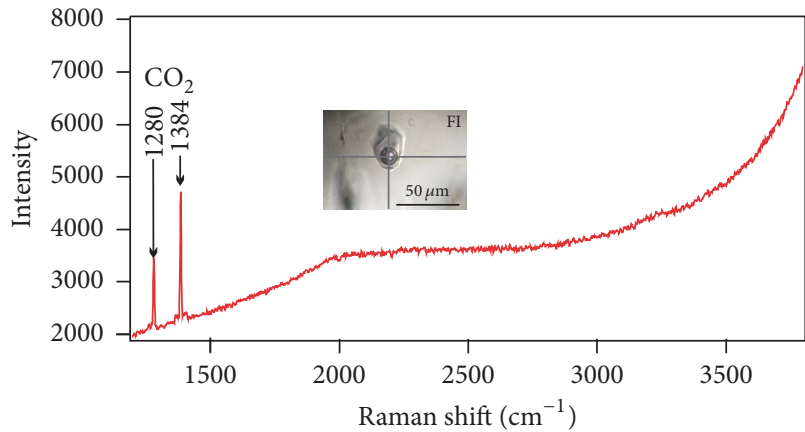

(c)

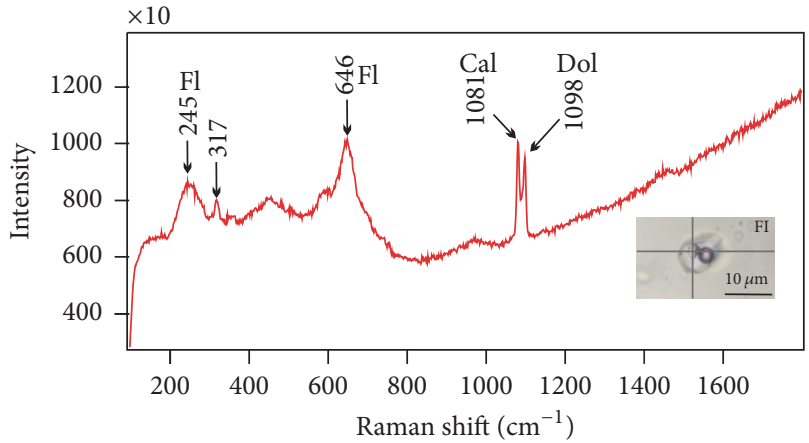

(e)

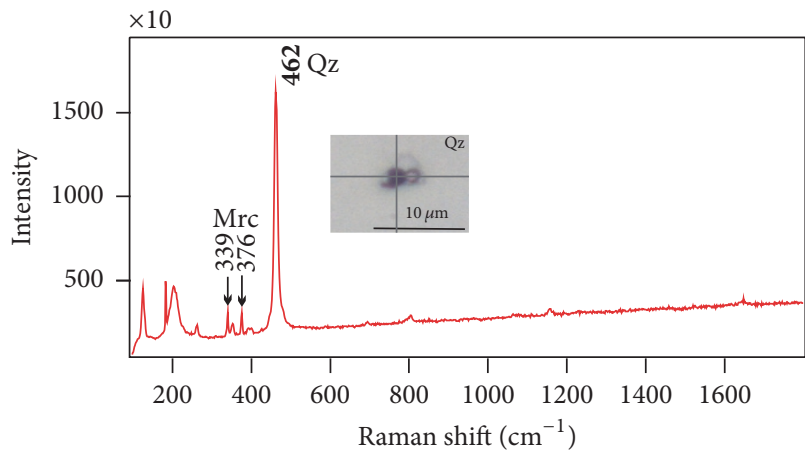

(g)

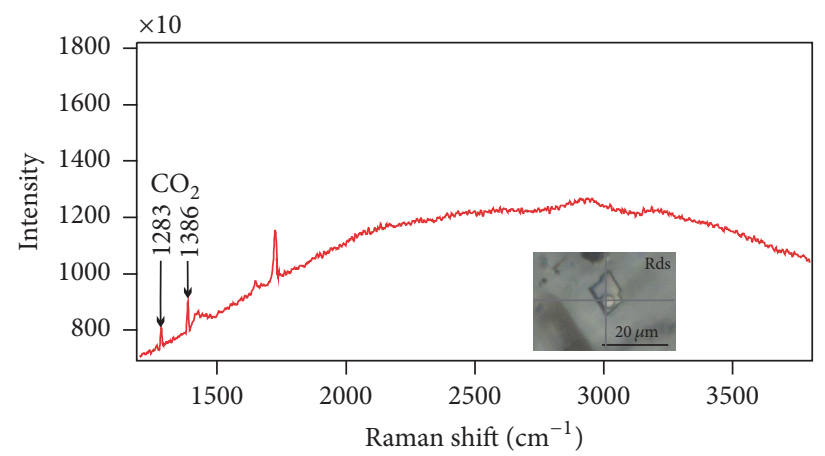

(b)

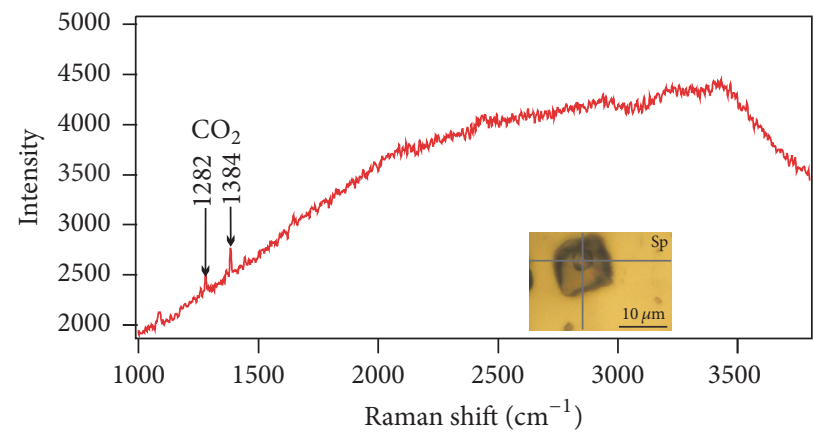

(d)

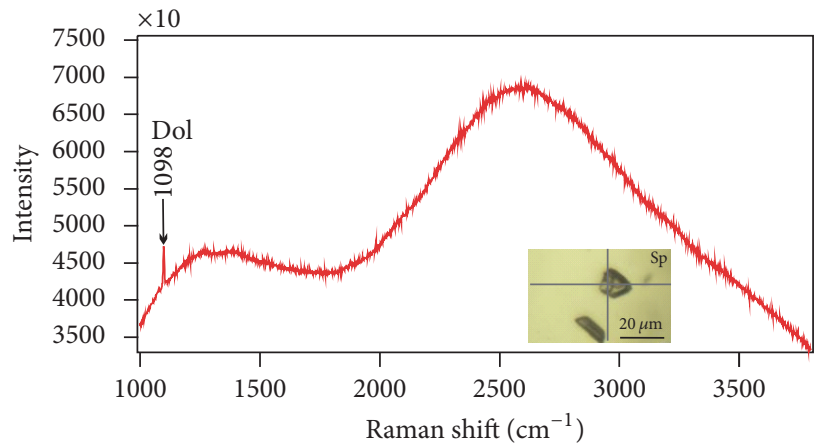

(f)

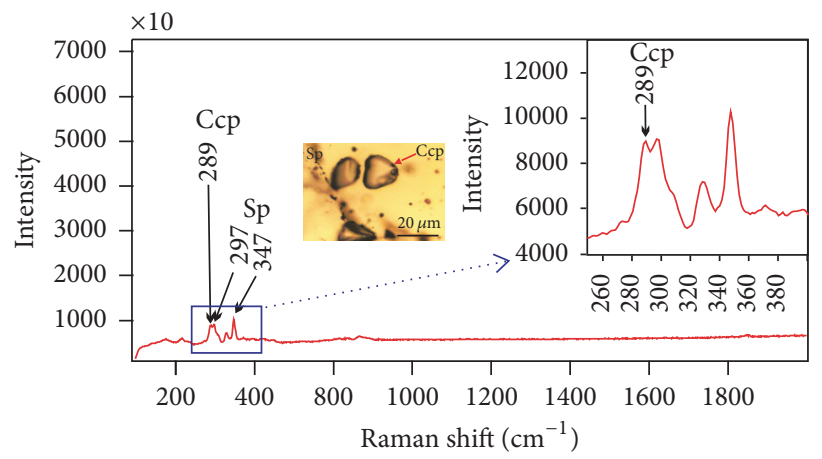

(h)

FIGURE 8: Laser Raman spectroscopy of different fluid inclusions (FIs). (a) $\mathrm{CO}_{2}$ spectra of vapour in C-type FIs in the early stage quartz; (b) $\mathrm{CO}_{2}$ spectra of vapour in a few W-type FIs in the main stage rhodochrosite; (c) $\mathrm{CO}_{2}$ spectra of vapour in C-type FIs in the main stage fluorite; (d) $\mathrm{CO}_{2}$ spectra of vapour in C-type FIs in the main stage sphalerite; (e) transparent daughter minerals in S-type FIs of fluorite being calcite and dolomite; (f) primary S-type FIs containing dolomite daughter mineral in sphalerite; (g) the opaque daughter mineral in the early stage quartz being marcasite; (h) the opaque daughter mineral in S-type FIs of the main stage sphalerite being chalcopyrite. Qz, quartz; Rds, rhodochrosite; Sp, sphalerite; Fl, fluorite; Cal, calcite; Dol, dolomite; Ccp, chalcopyrite; Mrc, marcasite. 


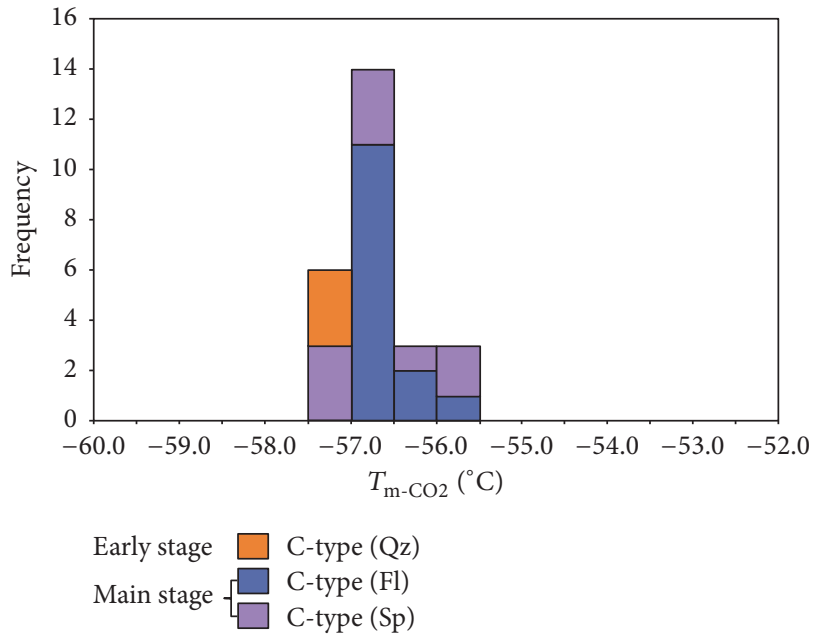

(a)

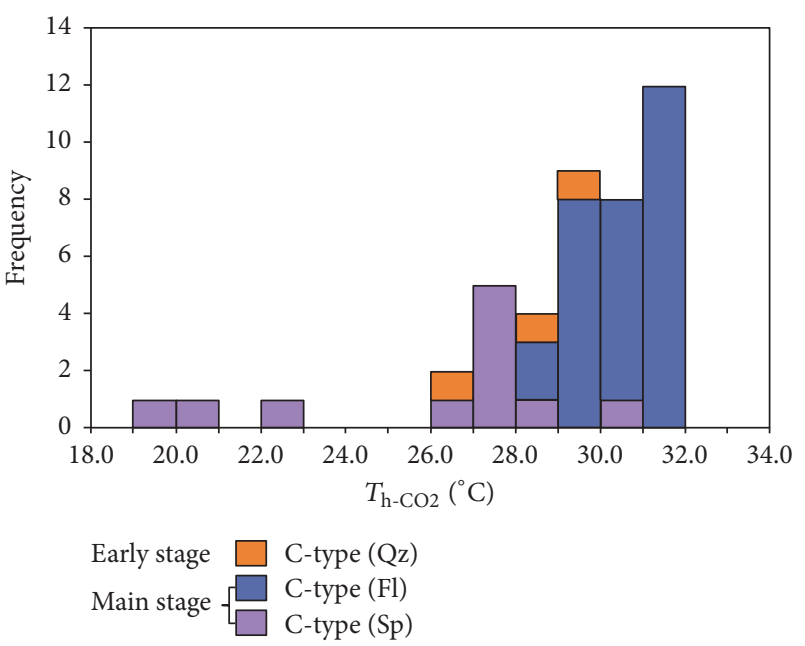

(b)

Figure 9: Histograms of $\mathrm{CO}_{2}$ melting temperature $\left(T_{\mathrm{m}-\mathrm{CO} 2}\right)(\mathrm{a})$ and homogenization temperature $\left(T_{\mathrm{h}-\mathrm{CO} 2}\right)$ of $\mathrm{CO}_{2}$ (b) in aqueous-carbonic (C-type) inclusions from different types of minerals in the early and main stages. Qz, quartz; Rds, rhodochrosite; Sp, sphalerite; Fl, fluorite.

TABLE 1: Microthermometric data of fluid inclusions from different stages in the Zhijiadi Ag-Pb-Zn deposit.

\begin{tabular}{|c|c|c|c|c|c|c|c|c|c|c|c|}
\hline Stages & Mineral & Type & Number & $T_{\mathrm{m}, \mathrm{CO} 2}\left({ }^{\circ} \mathrm{C}\right)$ & $T_{\text {m,cla }}\left({ }^{\circ} \mathrm{C}\right)$ & $T_{\mathrm{h}, \mathrm{CO} 2}\left({ }^{\circ} \mathrm{C}\right)$ & $T_{\text {m,ice }}\left({ }^{\circ} \mathrm{C}\right)$ & $T_{\mathrm{h}}\left({ }^{\circ} \mathrm{C}\right)$ & $\begin{array}{c}\text { Salinity } \\
\text { (wt.\% } \\
\mathrm{NaCl} \\
\text { equiv.) }\end{array}$ & $\begin{array}{c}\mathrm{CO}_{2} \\
\text { density } \\
\left(\mathrm{g} / \mathrm{cm}^{3}\right)\end{array}$ & $\begin{array}{c}\text { Bulk } \\
\text { density } \\
\left(\mathrm{g} / \mathrm{cm}^{3}\right)\end{array}$ \\
\hline \multirow{2}{*}{$\begin{array}{l}\text { Early } \\
\text { stage }\end{array}$} & \multirow[t]{2}{*}{$\mathrm{Qz}$} & $\mathrm{C}$ & 4 & -57.4 to -57.1 & $5.5-6.8$ & $25.6-29.2$ & & $294-298$ & $6.1-8.3$ & $0.65-0.70$ & $0.98-1.00$ \\
\hline & & $\mathrm{W}$ & 42 & & & & -7.5 to -2.4 & $244-334$ & $4.0-9.9$ & & $0.74-0.87$ \\
\hline \multirow{5}{*}{$\begin{array}{l}\text { Main } \\
\text { stage }\end{array}$} & Rds & $\mathrm{W}$ & 80 & & & & -8.9 to -1.9 & $188-298$ & $3.2-12.7$ & & $0.77-1.08$ \\
\hline & $\mathrm{Fl}$ & $\mathrm{C}$ & 21 & -57.4 to -56.4 & $7.1-7.9$ & $29.5-31.1$ & & $197-268$ & $4.3-5.6$ & $0.47-0.62$ & $0.92-0.99$ \\
\hline & \multirow{3}{*}{ Sp } & $\mathrm{W}$ & 17 & & & & -5.3 to -0.3 & $194-278$ & $0.5-8.3$ & & $0.82-0.91$ \\
\hline & & $\mathrm{C}$ & 7 & -57.3 to -55.8 & $6.2-8.9$ & $20.7-27.7$ & & $190-224$ & $2.2-3.9$ & $0.66-0.77$ & $0.90-0.96$ \\
\hline & & $\mathrm{W}$ & 23 & & & & -5.9 to -1.3 & $164-245$ & $2.2-9.1$ & & $0.86-0.96$ \\
\hline \multirow{2}{*}{$\begin{array}{l}\text { Late } \\
\text { stage }\end{array}$} & $\mathrm{Fl}$ & $\mathrm{W}$ & 22 & & & & -4.6 to -0.2 & $115-174$ & $0.2-7.3$ & & $0.91-0.96$ \\
\hline & $\mathrm{Sp}$ & $\mathrm{W}$ & 14 & & & & -5.7 to -1.0 & $111-152$ & $1.7-8.8$ & & $0.94-0.99$ \\
\hline
\end{tabular}

$\mathrm{W}$, aqueous inclusion; $\mathrm{C}$, aqueous-carbonic inclusion; $T_{\mathrm{m}, \mathrm{CO} 2}$, melting temperature of solid $\mathrm{CO}_{2} ; T_{\mathrm{m}, \mathrm{cla}}$, temperature of $\mathrm{CO}_{2}$-clathrate dissociation; $T_{\mathrm{h}, \mathrm{CO} 2}$, homogenization temperature of $\mathrm{CO}_{2} ; T_{\mathrm{m} \text {,ice }}$, ice-melting temperature; $T_{\mathrm{h}}$, total homogenization temperature. All of fluid inclusions including W-type and Ctype FIs homogenize into the liquid phase.

heated, the vapour phase disappeared with the temperature of $200-260^{\circ} \mathrm{C}$; however these daughter minerals remained to be stable in size with the temperature up to $450^{\circ} \mathrm{C}$. Considering that the S-type FIs were not completely homogenized, the microthermometric data of S-type FIs are not included in Table 1.

In the early stage, the $\mathrm{W}$ - and C-type FIs are recognized as primary FIs in the quartz grain. The melting temperatures $\left(T_{\mathrm{m}-\mathrm{CO} 2}\right)$ of solid $\mathrm{CO}_{2}$ in the C-type FIs range from -57.4 to $-57.1^{\circ} \mathrm{C}$, which are similar to the triple point for pure $\mathrm{CO}_{2}\left(-56.6^{\circ} \mathrm{C}\right)$. Clathrate melting temperatures $\left(T_{\mathrm{m}-\mathrm{cla}}\right)$ vary from 5.5 to $6.8^{\circ} \mathrm{C}$, with which the salinities are calculated to be 6.1 to $8.3 \mathrm{wt} . \% \mathrm{NaCl}$ equivalent by the equation of Hall et al. [40]. Homogenization temperatures $\left(T_{\mathrm{h}-\mathrm{CO} 2}\right)$ of the carbonic phase to the liquid phase are between 25.6 and $29.2^{\circ} \mathrm{C}$. The total homogenization temperatures $\left(T_{\mathrm{h}}\right)$ of $\mathrm{C}$ type FIs to the liquid phase range from 294 to $298^{\circ} \mathrm{C}$. The $\mathrm{CO}_{2}$ densities are estimated to be from 0.65 to $0.70 \mathrm{~g} / \mathrm{cm}^{3}$, and their bulk densities range from 0.98 to $1.00 \mathrm{~g} / \mathrm{cm}^{3}$. Wtype FIs yield the ice-melting temperatures $\left(T_{\mathrm{m} \text {-ice }}\right)$ from -7.5 to $-2.4^{\circ} \mathrm{C}$, and their salinities are estimated to be 4.0 to $9.9 \mathrm{wt} . \% \mathrm{NaCl}$ equivalent by the equation of Roedder [41]. These FIs completely homogenize to the liquid phase at temperatures $\left(T_{\mathrm{h}}\right)$ of $244-334^{\circ} \mathrm{C}$. Their densities are also acquired, fluctuating from 0.74 to $0.87 \mathrm{~g} / \mathrm{cm}^{3}$ (Table 1).

In the main stage, three transparent minerals are measured for the microthermometry, including rhodochrosite, fluorite, and sphalerite. 


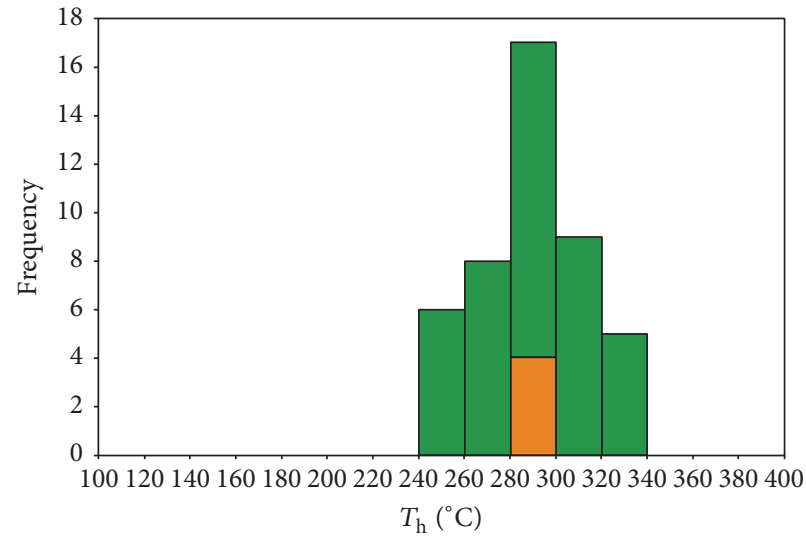

$\left.\begin{array}{l}\text { W-type } \\ \text { C-type }\end{array}\right] \mathrm{Qz}$

(a)

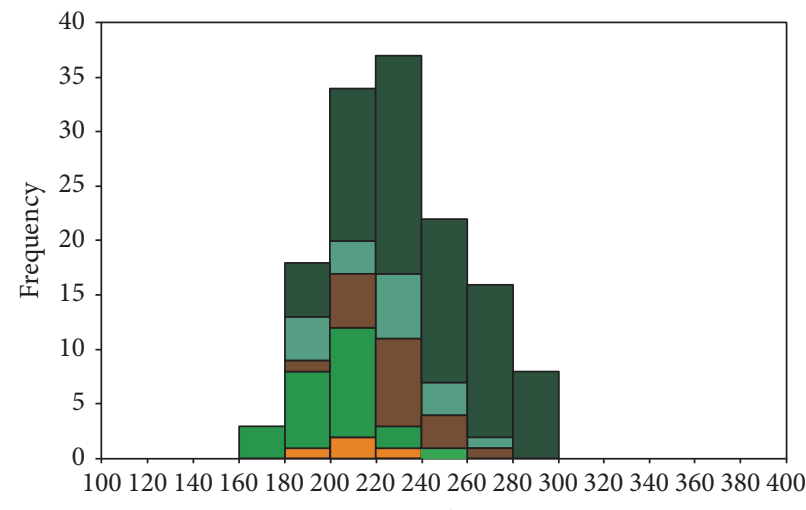

$\mathrm{T}_{\mathrm{h}}\left({ }^{\circ} \mathrm{C}\right)$

W-type Rds

$\left.\begin{array}{l}\text { W-type } \\ \text { C-type }\end{array}\right]$ FI

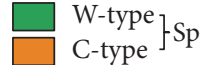

(c)

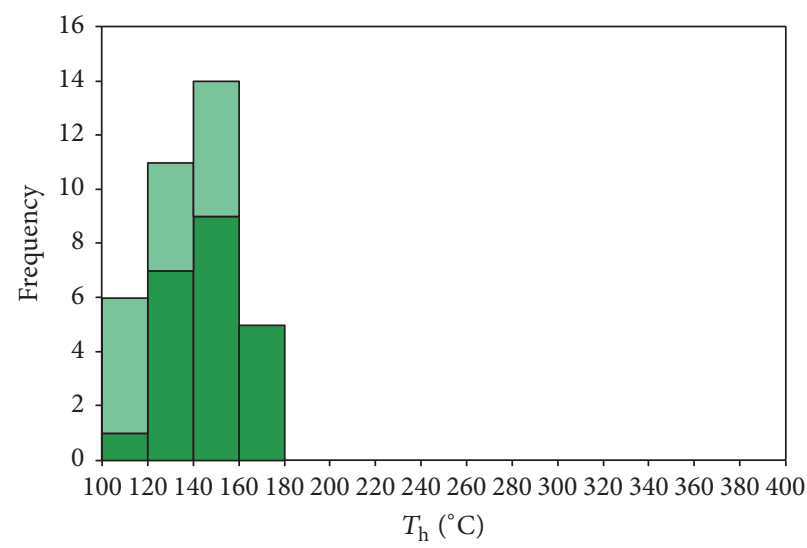

W-type Sp

W-type Fl

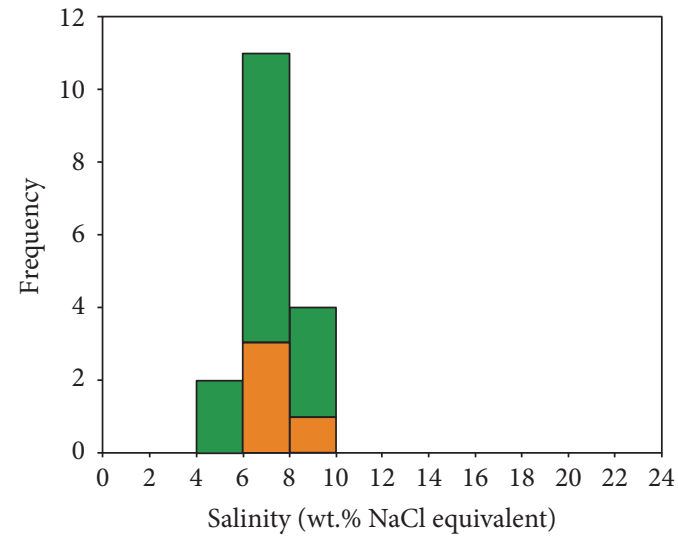

$\left.\begin{array}{l}\text { W-type } \\ \text { C-type }\end{array}\right\} \mathrm{Qz}$

(b)

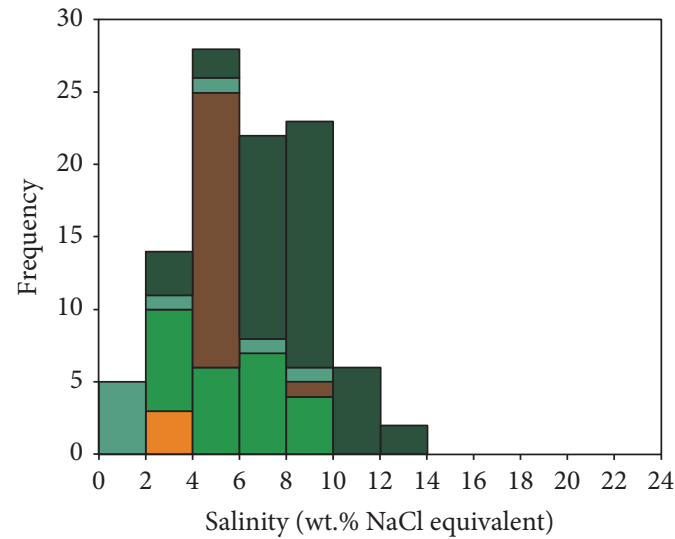

W-type Rds

W-type ${ }_{\text {C-type }}$ FI

$\begin{aligned} & \text { W-type } \\ & \text { C-type }\end{aligned}-\mathrm{Sp}$

(d)

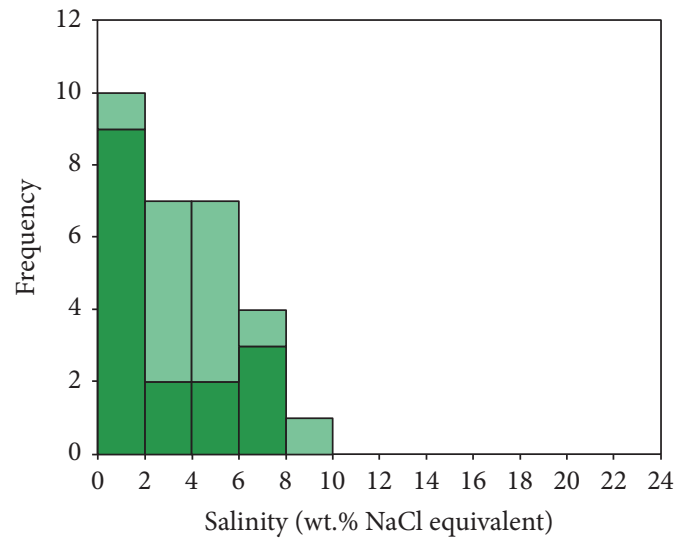

W-type Sp

W-type Fl

(e)

(f)

FIgURE 10: Histograms of homogenization temperatures $\left(T_{\mathrm{h}}\right)$ and salinities of C-type and W-type fluid inclusions in the early stage (a, b), the main stage $(c, d)$, and secondary W-type fluid inclusions from fluorite and sphalerite which represent the late stage (e, f). Qz, quartz; Rds, rhodochrosite; $\mathrm{Sp}$, sphalerite; Fl, fluorite. 
In rhodochrosite crystals, ice-melting temperatures $\left(T_{\text {m-ice }}\right)$ of W-type FIs range from -8.9 to $-1.9^{\circ} \mathrm{C}$, with corresponding salinities from 3.2 to $12.7 \mathrm{wt} . \% \mathrm{NaCl}$ equivalent. They are homogenized into the liquid phase at the temperatures of 188 to $298^{\circ} \mathrm{C}$, and their densities are 0.86 to $0.96 \mathrm{~g} / \mathrm{cm}^{3}$.

Fluorite crystals from the main stage contain abundant $\mathrm{C}$ - and $\mathrm{W}$-type FIs. The C-type FIs have narrow $T_{\mathrm{m}-\mathrm{CO} 2}$ range from -57.4 to $-56.4^{\circ} \mathrm{C}$. The $\mathrm{CO}_{2}$ clathrate was melted at the temperatures of 7.1 to $7.9^{\circ} \mathrm{C}$, corresponding to salinities of 4.3 to $5.6 \mathrm{wt} . \% \mathrm{NaCl}$ equivalent. The homogenization temperatures $\left(T_{\mathrm{h}-\mathrm{CO} 2}\right)$ range from 29.5 to $31.1^{\circ} \mathrm{C}$. The $\mathrm{CO}_{2}$ densities and total densities are estimated to be $0.47-0.62 \mathrm{~g} / \mathrm{cm}^{3}$ and $0.92-0.99 \mathrm{~g} / \mathrm{cm}^{3}$, respectively. The C-type FIs show a total homogenization (all homogenized to liquid) at temperatures from 197 to $268^{\circ} \mathrm{C}$. These W-type FIs yield final ice-melting temperatures $\left(T_{\mathrm{m} \text {-ice }}\right)$ of -5.3 to $-0.3^{\circ} \mathrm{C}$ and the salinities of 0.5 to $8.3 \mathrm{wt} . \% \mathrm{NaCl}$ equivalent. They homogenized to the liquid phase at the temperatures of 194 to $278^{\circ} \mathrm{C}$.

FIs in sphalerite are mainly composed of C- and Wtype FIs. The solid $\mathrm{CO}_{2}$ yields the melting temperatures $\left(T_{\mathrm{m}-\mathrm{CO} 2}\right)$ of -57.3 to $-55.8^{\circ} \mathrm{C}$. The $T_{\mathrm{m}-\text { cla }}$ are between 6.2 and $8.9^{\circ} \mathrm{C}$, which correspond to the salinities from 2.2 to $3.9 \mathrm{wt} . \%$ $\mathrm{NaCl}$ equivalent. The homogenization temperatures $\left(T_{\mathrm{h}-\mathrm{CO} 2}\right)$ vary from 20.7 to $27.7^{\circ} \mathrm{C}$, and the total homogenization temperatures $\left(T_{\mathrm{h}}\right)$ of these C-type FIs into the liquid phase span from 190 to $224^{\circ} \mathrm{C}$. Their $\mathrm{CO}_{2}$ densities are estimated to be $0.66-0.77 \mathrm{~g} / \mathrm{cm}^{3}$, and their bulk densities are from 0.90 to $0.96 \mathrm{~g} / \mathrm{cm}^{3} . T_{\mathrm{m} \text {-ice }}$ of the $\mathrm{W}$-type range from -5.9 to $-1.3^{\circ} \mathrm{C}$, corresponding to salinities of $2.2-9.1 \mathrm{wt} . \% \mathrm{NaCl}$ equivalent. The W-type FIs totally homogenize to the liquid phase at $164-245^{\circ} \mathrm{C}$, with the calculated densities of $0.86-0.96 \mathrm{~g} / \mathrm{cm}^{3}$.

As a result of the extremely small size of quartz and carbonate grains, unfortunately, none of FIs has been measured in quartz-calcite-dolomite veins. Lu et al. [50] proposed that the secondary fluid inclusions could provide clues to study the nature of fluids after mineral crystallization. Furthermore, this view was also supported by Peng et al. [39], who reported that the characteristics of secondary FIs at the main stage (quartz and calcite veins) are similar to these of primary FIs at the late stage (calcite veins) in the Hongniu-Hongshan $\mathrm{Cu}$ skarn deposit. So we chose secondary W-type FIs in the fluorite and sphalerite in the main stage try to represent the characteristics of the late stage in the Zhijiadi deposit. Many secondary W-type FIs observed in the grains of fluorite and sphalerite have been measured in this study. All these kinds of FIs homogenize into the liquid phase. These W-type FIs in fluorite completely homogenize at the temperatures of $115-174^{\circ} \mathrm{C}$. Their $T_{\text {m-ice }}$ vary from -4.6 to $-0.2^{\circ} \mathrm{C}$ with the calculated salinities of $0.2-7.3 \mathrm{wt} . \% \mathrm{NaCl}$ equivalent. Similar to them, those FIs in the sphalerite have the icemelting temperatures $\left(T_{\text {m-ice }}\right)$ of -5.7 to $-1.0^{\circ} \mathrm{C}$, and the salinities are estimated to be $1.7-8.8 \mathrm{wt} . \% \mathrm{NaCl}$ equivalent. The homogenization temperatures $\left(T_{\mathrm{h}}\right)$ range from 111 to $152^{\circ} \mathrm{C}$.

5.4. Carbon and Oxygen Isotopic Compositions. The C-O isotopic compositions of eight rhodochrosite samples from

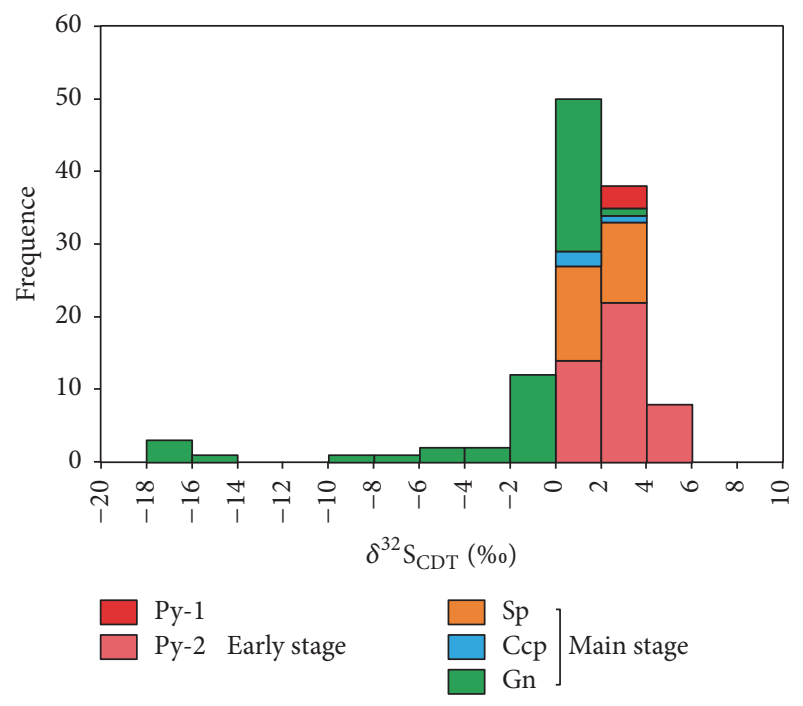

FIGURE 11: Sulfur isotope values of sulfide minerals from the Zhijiadi deposit. The values are expressed in per mil, related to the standard V-CDT (Vienna Canyon Diablo Troilite). Py-1, pyrite disseminated in quartz porphyry, Py-2, pyrite in ores; Sp, sphalerite; Ccp, chalcopyrite; Gn, galena.

the Zhijiadi deposit are given in Table 2. The $\delta^{13} \mathrm{C}_{\mathrm{V}-\mathrm{PDB}}$ values vary from $-2.8 \%$ o to $-4.4 \%$, with an average of $-3.0 \%$. The $\delta^{18} \mathrm{O}_{\mathrm{V} \text {-PDB }}$ values range from $-14.4 \%$ to $-17.5 \%$, with an average of $-16.6 \%$. The $\delta^{18} \mathrm{O}_{\mathrm{V}-\text { sMOw }}$ values are calculated to be $12.8 \%$ to $16.03 \%$, and their average value is $-13.7 \%$. The $\mathrm{C}$ and $\mathrm{O}$ isotopic compositions are relatively homogenous in the rhodochrosite.

5.5. Sulfur Isotopic Compositions. One hundred and eighteen in situ LA-MC-ICP-MS sulfur isotopic compositions were determined from one quartz porphyry sample ( 3 in pyrite) and thirteen ore samples (44 in pyrite, 24 in sphalerite, 44 in galena, and 3 in chalcopyrite) covering the early and main stages. The results are shown in Table 3 and Figure 11.

The $\delta^{34} \mathrm{~S}$ values of pyrite in quartz porphyry are from $2.3 \%$ to $3.0 \%$ o $(n=3$, avg. $2.7 \%$ ), while pyrite in quartzpyrite vein (the early stage) has $\delta^{34} \mathrm{~S}$ values of $+0.2 \%$ to $+5.5 \%$ o $\left(n=44\right.$, avg. 2.8\%o; Figure 11). The $\delta^{34} \mathrm{~S}$ values of sulfides in the main stage (sphalerite, chalcopyrite, and galena) are slightly negative in comparison with those of the early stage; for example, sphalerite (from $0 \%$ to $+3.3 \%$, $n=24$, avg. $1.8 \%$ ), chalcopyrite (from $+1.1 \%$ to $+3.0 \%$, $n=3$, avg. $1.7 \%$ ), and the galena sample have the most negative sulfur isotopic values of $-17.0 \%$ o to $2.9 \%$ o $(n=44$, avg. $-1.8 \%$ ).

As a whole, the $\delta^{34} S$ values of sulfides in the Zhijiadi deposit show a decreasing sequence of $\delta^{34} \mathrm{~S}_{\mathrm{Py}}(2.8 \% 0)>$ $\delta^{34} \mathrm{~S}_{\mathrm{Sp}}(1.8 \%)>\delta^{34} \mathrm{~S}_{\mathrm{Ccp}}(1.7 \%)>\delta^{34} \mathrm{~S}_{\mathrm{Gn}}(-1.8 \%)$, which is consistent with the $\delta^{34} \mathrm{~S}$ enrichment at the equilibrium conditions of sulfur isotope fractionation [51]. Hence, the sulfur isotopic equilibrium temperatures of mineral pair 


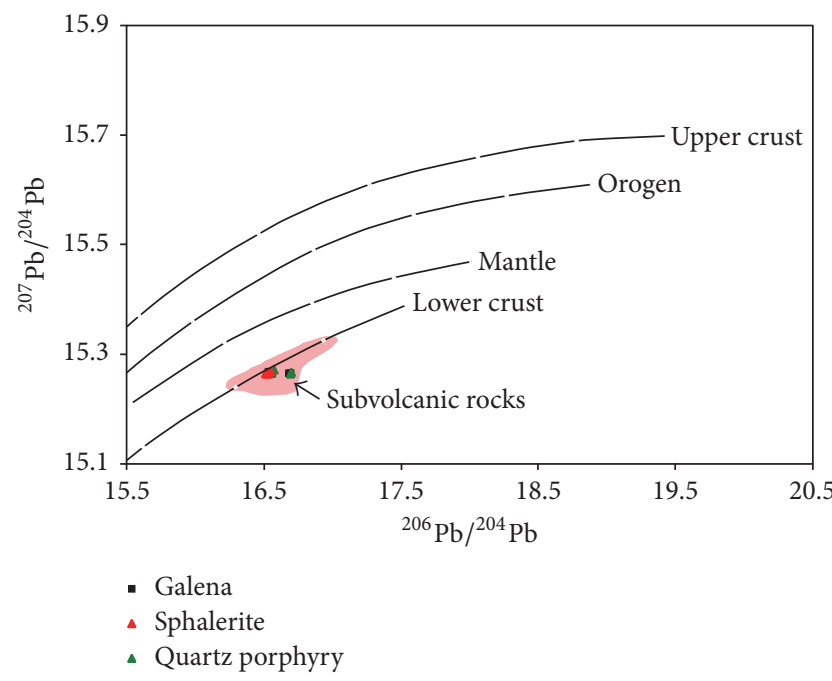

(a)

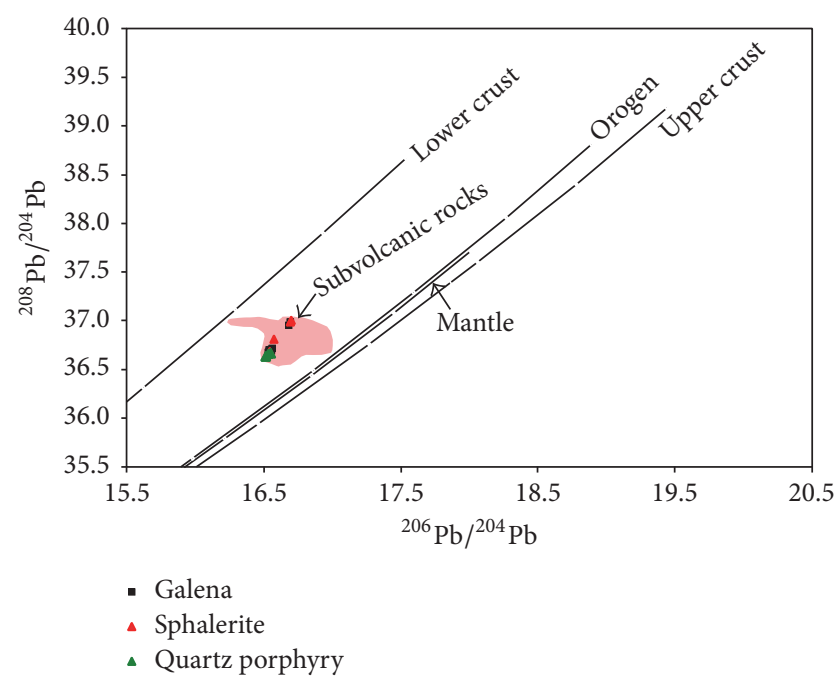

(b)

Figure 12: Plot of ${ }^{208} \mathrm{~Pb} /{ }^{204} \mathrm{~Pb}$ versus ${ }^{206} \mathrm{~Pb} /{ }^{204} \mathrm{~Pb}$ (a) and ${ }^{207} \mathrm{~Pb} /{ }^{204} \mathrm{~Pb}$ versus ${ }^{206} \mathrm{~Pb} /{ }^{204} \mathrm{~Pb}$ (b) for the sulfides (sphalerite and galena) and quartz porphyry (subvolcanic rocks) from the Zhijiadi deposit. The base map is from [34]. These ranges of subvolcanic rocks (quartz porphyry and granite porphyry) are quoted from the data of [35].

TABle 2: Carbon and oxygen isotope data of rhodochrosite from the Zhijiadi Ag-Pb-Zn deposit.

\begin{tabular}{llccc}
\hline Sample ID & Mineral & $\delta^{13} \mathrm{C}_{\mathrm{V}-\mathrm{PDB}}(\%)$ & $\delta^{18} \mathrm{O}_{\mathrm{V}-\mathrm{PDB}}(\%)$ & $\delta^{18} \mathrm{O}_{\mathrm{V}-\mathrm{SMOW}}(\%)$ \\
\hline Z1320-6 & Rhodochrosite & -3.2 & -16.8 & 13.6 \\
Z1320-4 & Rhodochrosite & -4.2 & -16.4 & 13.9 \\
16ZJD-8 & Rhodochrosite & -2.9 & -17.4 & 12.9 \\
16ZJD-9 & Rhodochrosite & -2.8 & -16.5 & 16.0 \\
16ZJD-11 & Rhodochrosite & -4.4 & -16.8 & 13.9 \\
16ZJD-18 & Rhodochrosite & -3.8 & -17.2 & 13.5 \\
ZK2207-66 & Rhodochrosite & -2.7 & -17.5 & 13.2 \\
16ZJD-10 & Rhodochrosite & -2.5 & & 12.8 \\
\hline
\end{tabular}

(sphalerite and galena) can be calculated using the fractionation equation [51]. The equilibrium temperatures for mineral pair of sphalerite and galena are estimated to be 237 to $267^{\circ} \mathrm{C}$.

5.6. Lead Isotopic Compositions. The lead isotope data of sulfides (galena and sphalerite separates) and the Early Cretaceous quartz porphyry are shown in Table 4 . The ratios of ${ }^{206} \mathrm{~Pb} /{ }^{204} \mathrm{~Pb},{ }^{207} \mathrm{~Pb} /{ }^{204} \mathrm{~Pb}$, and ${ }^{208} \mathrm{~Pb} /{ }^{204} \mathrm{~Pb}$ for sulfides have relatively uniform $\mathrm{Pb}$ isotopic composition, varying from 16.5323 to $16.6934,15.2634$ to 15.2712 , and 36.6673 to 36.9998 , respectively. The Early Cretaceous quartz porphyry shows a narrow range, with ${ }^{206} \mathrm{~Pb} /{ }^{204} \mathrm{~Pb}$ of 16.5104 to 16.5500 , ${ }^{207} \mathrm{~Pb} /{ }^{204} \mathrm{~Pb}$ of 15.2631 to 15.2677 , and ${ }^{208} \mathrm{~Pb} /{ }^{204} \mathrm{~Pb}$ of 36.6289 to 36.6623 , which is consistent with the previous studies of the subvolcanic rocks (quartz porphyry and granite porphyry) [35]. In addition, all lead isotope data of sulfides are plotted into the area of subvolcanic rocks (Figure 12).

5.7. EPMA Data of Sphalerite. A total of seven electron microprobe spot analyses were performed in sphalerite. The EPMA data for the main stage are summarized in Table 5.
Among all the analytical elements, $\mathrm{Ga}, \mathrm{Cd}$, and $\mathrm{Pb}$ are mostly below the detection limit. The concentration of $\mathrm{Cu}$ in the sphalerite is very low $(<0.14 \mathrm{wt} . \%)$, and that of Fe ranges from $0.67 \mathrm{wt} . \%$ to $3.34 \mathrm{wt} . \%$. The variations of $\mathrm{Zn}$ and $\mathrm{S}$ atomic percent in sphalerite are from $62.77 \mathrm{wt} . \%$ to $66.20 \mathrm{wt} . \%$ and from 33.19 to $33.93 \mathrm{wt} \%$, respectively. The average of $\mathrm{Cu}$, $\mathrm{Ge}, \mathrm{Ga}, \mathrm{Cd}, \mathrm{Pb}, \mathrm{Pb}, \mathrm{Fe}, \mathrm{Zn}$, and $\mathrm{S}$ is 0.07 wt.\%, 0.02 wt.\%, 0.05 wt. $\%, 0.51$ wt. $\%, 0.03$ wt. $\%, 2.26$ wt. $\%, 64.13$ wt. $\%$, and 33.59 wt.\%, respectively. The hydrothermal fluid temperatures are calculated using the correlation of the $\mathrm{Fe} / \mathrm{Zn}$ ratios in the linear equation to be 236 to $275^{\circ} \mathrm{C}$ [49].

\section{Discussion}

6.1. Nature and Evolution of Ore-Forming Fluids. Carbon dioxide $\left(\mathrm{CO}_{2}\right)$ is a common component of ore-forming fluids in orogenic-type and granitic intrusion-related ore deposits [52-54]. It is widely accepted that $\mathrm{CO}_{2}$ plays a critical role during metal transport by buffering the fluid in a $\mathrm{pH}$ range where elevated metal concentration can be maintained by complexation with reduced sulfur $[55,56]$. On the other hand, the abundance of C-type FIs and the content of $\mathrm{CO}_{2}$ 
TABLE 3: Sulfur isotope data of sulfide minerals from the Zhijiadi Ag-Pb-Zn deposit.

\begin{tabular}{|c|c|c|c|c|}
\hline Number & Sample ID & Description & Mineral & $\begin{array}{c}\delta^{34} \mathrm{~S}_{\mathrm{V}-\mathrm{CDT}} \\
(\% \mathrm{o})\end{array}$ \\
\hline \multirow{27}{*}{ (1) } & \multirow{27}{*}{ 16ZJD-28 } & \multirow{27}{*}{ Massive } & Py & 1.1 \\
\hline & & & Py & 0.5 \\
\hline & & & $\mathrm{Py}$ & 1.2 \\
\hline & & & Py & 0.2 \\
\hline & & & $\mathrm{Py}$ & 4.3 \\
\hline & & & $S p$ & 0.5 \\
\hline & & & $\mathrm{Sp}$ & 0.7 \\
\hline & & & $\mathrm{Sp}$ & 0.0 \\
\hline & & & $\mathrm{Sp}$ & 0.7 \\
\hline & & & $\mathrm{Sp}$ & 0.6 \\
\hline & & & $S p$ & 0.8 \\
\hline & & & $\mathrm{Sp}$ & 0.7 \\
\hline & & & Ccp & 1.1 \\
\hline & & & Ccp & 1.1 \\
\hline & & & $\mathrm{Gn}$ & -1.1 \\
\hline & & & $\mathrm{Gn}$ & -0.7 \\
\hline & & & $\mathrm{Gn}$ & -1.5 \\
\hline & & & $\mathrm{Gn}$ & -2.4 \\
\hline & & & $\mathrm{Gn}$ & -9.0 \\
\hline & & & $\mathrm{Gn}$ & -16.8 \\
\hline & & & $\mathrm{Gn}$ & -7.1 \\
\hline & & & $\mathrm{Gn}$ & -17.0 \\
\hline & & & $\mathrm{Gn}$ & -5.4 \\
\hline & & & $\mathrm{Gn}$ & -4.3 \\
\hline & & & $\mathrm{Gn}$ & -3.9 \\
\hline & & & $\mathrm{Gn}$ & -14.9 \\
\hline & & & $\mathrm{Gn}$ & -16.2 \\
\hline \multirow{13}{*}{ (2) } & \multirow{13}{*}{ 16ZJD-29 } & \multirow{13}{*}{ Stockwork } & $\mathrm{Py}$ & 2.0 \\
\hline & & & $\mathrm{Py}$ & 1.6 \\
\hline & & & Py & 3.9 \\
\hline & & & Py & 4.3 \\
\hline & & & Py & 3.8 \\
\hline & & & Py & 2.4 \\
\hline & & & Py & 2.7 \\
\hline & & & Py & 1.1 \\
\hline & & & Py & 3.3 \\
\hline & & & Py & 2.7 \\
\hline & & & Py & 2.6 \\
\hline & & & Py & 3.5 \\
\hline & & & $\mathrm{Gn}$ & 0.0 \\
\hline \multirow{7}{*}{ (3) } & \multirow{7}{*}{ 16ZJD-31 } & \multirow{7}{*}{ Massive } & $\mathrm{Gn}$ & 1.3 \\
\hline & & & $\mathrm{Gn}$ & 1.7 \\
\hline & & & $\mathrm{Gn}$ & 1.8 \\
\hline & & & $\mathrm{Gn}$ & 1.6 \\
\hline & & & Gn & 1.2 \\
\hline & & & Gn & 1.7 \\
\hline & & & $\mathrm{Gn}$ & 1.0 \\
\hline \multirow{5}{*}{ (4) } & \multirow{5}{*}{ 16ZJD-38 } & \multirow{5}{*}{$\begin{array}{c}\text { Veinlet- } \\
\text { disseminated }\end{array}$} & Py & 4.0 \\
\hline & & & Py & 3.9 \\
\hline & & & Py & 4.6 \\
\hline & & & $\mathrm{Sp}$ & 3.3 \\
\hline & & & $\mathrm{Gn}$ & 0.4 \\
\hline \multirow{3}{*}{ (5) } & \multirow{3}{*}{ ZK2207-36 } & \multirow{3}{*}{$\begin{array}{l}\text { Granite } \\
\text { porphyry }\end{array}$} & $\mathrm{Py}$ & 2.3 \\
\hline & & & $\mathrm{Py}$ & 2.8 \\
\hline & & & Py & 3.0 \\
\hline
\end{tabular}

TABLE 3: Continued.

\begin{tabular}{|c|c|c|c|c|}
\hline Number & Sample ID & Description & Mineral & $\begin{array}{c}\delta^{34} \mathrm{~S}_{\mathrm{V}-\mathrm{CDT}} \\
(\% \circ)\end{array}$ \\
\hline \multirow{4}{*}{ (6) } & \multirow{4}{*}{ ZK2207-89 } & \multirow{4}{*}{$\begin{array}{c}\text { Veinlet- } \\
\text { disseminated }\end{array}$} & Py & 3.3 \\
\hline & & & $\mathrm{Sp}$ & 3.8 \\
\hline & & & Py & 5.1 \\
\hline & & & $\mathrm{Sp}$ & 3.4 \\
\hline \multirow{7}{*}{ (7) } & \multirow{7}{*}{ 16ZJD-2 } & \multirow{7}{*}{ Stockwork } & Py & 2.8 \\
\hline & & & Py & 3.1 \\
\hline & & & $\mathrm{Gn}$ & 0.8 \\
\hline & & & $\mathrm{Gn}$ & 1.5 \\
\hline & & & $\mathrm{Gn}$ & 0.9 \\
\hline & & & $\mathrm{Sp}$ & 3.3 \\
\hline & & & $\mathrm{Gn}$ & 0.5 \\
\hline \multirow{4}{*}{ (8) } & \multirow{4}{*}{ 16ZJD-6 } & \multirow{4}{*}{ Vein } & $\mathrm{Sp}$ & 1.4 \\
\hline & & & $\mathrm{Gn}$ & -1.0 \\
\hline & & & $\mathrm{Sp}$ & 0.9 \\
\hline & & & $\mathrm{Gn}$ & -1.0 \\
\hline \multirow{15}{*}{ (9) } & \multirow{15}{*}{ 16ZJD-7 } & \multirow{15}{*}{ Brecciated } & Py & 2.4 \\
\hline & & & Py & 1.5 \\
\hline & & & Py & 0.5 \\
\hline & & & Py & 3.7 \\
\hline & & & Py & 0.7 \\
\hline & & & Py & 3.7 \\
\hline & & & Py & 1.7 \\
\hline & & & Py & 0.7 \\
\hline & & & $\mathrm{Sp}$ & 3.8 \\
\hline & & & $\mathrm{Sp}$ & 3.5 \\
\hline & & & $\mathrm{Sp}$ & 2.6 \\
\hline & & & $\mathrm{Sp}$ & 3.1 \\
\hline & & & $\mathrm{Gn}$ & -0.2 \\
\hline & & & Py & 3.5 \\
\hline & & & Gn & -0.3 \\
\hline \multirow{7}{*}{ (10) } & \multirow{7}{*}{ 16ZJD-17 } & \multirow{7}{*}{ Stockwork } & Py & 2.8 \\
\hline & & & $\mathrm{Py}$ & 2.4 \\
\hline & & & $\mathrm{Sp}$ & 2.0 \\
\hline & & & $\mathrm{Sp}$ & 0.6 \\
\hline & & & $\mathrm{Sp}$ & 2.6 \\
\hline & & & $\mathrm{Gn}$ & 0.2 \\
\hline & & & $\mathrm{Gn}$ & 0.9 \\
\hline \multirow{18}{*}{ (11) } & \multirow{8}{*}{ 16ZJD-13 } & \multirow{8}{*}{ Vein } & $\mathrm{Gn}$ & 0.3 \\
\hline & & & $\mathrm{Gn}$ & 0.8 \\
\hline & & & $\mathrm{Gn}$ & 1.3 \\
\hline & & & Py & 4.5 \\
\hline & & & $\mathrm{Gn}$ & 2.9 \\
\hline & & & $\mathrm{Gn}$ & 1.6 \\
\hline & & & $\mathrm{Gn}$ & 1.4 \\
\hline & & & $\mathrm{Gn}$ & 1.8 \\
\hline & \multirow{10}{*}{ 16ZJD-18 } & & Py & 5.5 \\
\hline & & & Py & 4.2 \\
\hline & & & $\mathrm{Sp}$ & 0.8 \\
\hline & & & $\mathrm{Sp}$ & 1.0 \\
\hline & & Massive & $\mathrm{Sp}$ & 1.6 \\
\hline & & & Gn & -0.5 \\
\hline & & & $\mathrm{Gn}$ & -0.5 \\
\hline & & & $\mathrm{Gn}$ & -0.5 \\
\hline & & & Py & 3.5 \\
\hline & & & $\mathrm{Sp}$ & 2.2 \\
\hline
\end{tabular}


TABLe 3: Continued.

\begin{tabular}{lcccc}
\hline Number & Sample ID & Description & Mineral & $\begin{array}{c}\delta^{34} \mathrm{~S}_{\mathrm{V}-\mathrm{CDT}} \\
(\%)\end{array}$ \\
\hline & & & $\mathrm{Py}$ & 4.1 \\
& & & $\mathrm{Py}$ & 2.8 \\
& & & $\mathrm{Sp}$ & 3.2 \\
& & & $\mathrm{Ccp}$ & 3.0 \\
& & & $\mathrm{Gn}$ & 0.4 \\
\hline \multirow{3}{*}{ 16ZJD-23 } & Stockwork & $\mathrm{Py}$ & 2.0 \\
& \multirow{3}{*}{ 16ZJD-27 } & Stockwork & $\mathrm{Py}$ & 1.8 \\
& & & $\mathrm{Gn}$ & -0.7
\end{tabular}

Note. The sulfur isotope equilibrium temperatures of mineral pair (sphalerite and galena) are calculated using the equilibrium fractionation equation [39]. In the sample 16ZJD-2, the sulfur isotope equilibrium temperature is estimated to be $237^{\circ} \mathrm{C}$ from mineral pair of sphalerite $\left(\delta^{34} \mathrm{~S}=3.3 \%\right.$ ) and galena $\left(\delta^{34} \mathrm{~S}=0.5 \%\right.$ ), while it is $267^{\circ} \mathrm{C}$ from mineral pair of sphalerite $\left(\delta^{34} \mathrm{~S}=1.4 \%\right.$ o $)$ and galena $\left(\delta^{34} \mathrm{~S}=-1.0 \%\right.$ ) in the sample 16ZJD-6. As a whole, the temperatures vary from 237 to $267^{\circ} \mathrm{C}$. Py, pyrite; Sp, sphalerite; Gn, galena; Ccp, chalcopyrite.

in ore-forming fluids give us an effective way to understand the nature of the ore-forming fluids and the genesis of some deposit; for example, Chi and Xue [25] confirmed the sedimentary basin-hosted Jinman Cu deposit in Yunnan was formed in a hydrothermal system rather than basinal mineralization system on the basis of the existence of a large number of $\mathrm{CO}_{2}$-rich FIs in this deposit; Lu et al. [50] proposed the content of $\mathrm{CO}_{2}$ in ore-forming fluids can be a marker for gold exploration; Chen et al. [24] also regard the content of $\mathrm{CO}_{2}$ as an important criterion for the division of different types of hydrothermal gold deposits. There are a large number of $\mathrm{CO}_{2}$-bearing (C-type) FIs having been observed and measured in the Zhijiadi Ag-Pb-Zn deposit, so it is possible to systemically and comprehensively constrain the nature of initial ore-forming fluids.

C-type FIs are distributed in the early quartz-pyrite veins. These C-type FIs are composed of two-phase and minor three-phase FIs and generally coexist with the W-type. Laser Raman spectroscopy shows that the gas phase of C-type FIs contains $\mathrm{CO}_{2}$. Their $T_{\mathrm{m}-\mathrm{CO} 2}$ temperatures range from -57.7 to $-57.1^{\circ} \mathrm{C}$, which are similar to the triple point for pure $\mathrm{CO}_{2}$ $\left(-56.6^{\circ} \mathrm{C}\right)$, showing that the carbonic phase in these FIs is nearly pure $\mathrm{CO}_{2}$. The peak homogenization temperature of these FIs (C-type and $\mathrm{W}$-type FIs) in the early stage ranges from 280 to $300^{\circ} \mathrm{C}$ (Figure 10(a)), and their salinities range from 4.0 to 9.9 wt.\% $\mathrm{NaCl}$ equivalent (Figure 10(b)). Hence, the initial ore-forming fluids are characterized by mediumlow temperature and low salinity and belong to a $\mathrm{NaCl}-\mathrm{H}_{2} \mathrm{O}-$ $\mathrm{CO}_{2}$ system.

Compared with the early stage, the main stage minerals mainly contain abundant C-type, W-type, and S-type FIs, especially fluorite and sphalerite crystals. These transparent daughter minerals in S-type FIs for fluorite and sphalerite are calcite and dolomite, determined by laser Raman spectroscopy, while a few opaque daughter minerals are detected as chalcopyrite in S-type FIs of the sphalerite. Although only W-type FIs are observed in rhodochrosite, laser Raman spectroscopy results have identified the peak of $\mathrm{CO}_{2}$ in the vapour bubble of some $\mathrm{W}$-type FIs. The low content of $\mathrm{CO}_{2}$ in FIs of rhodochrosite crystals could be the product of the reaction: $\mathrm{Mn}^{2+}+\mathrm{CO}_{3}{ }^{2+} \rightarrow \mathrm{MnCO}_{3} ; \mathrm{CO}_{2}+\mathrm{H}_{2} \mathrm{O} \rightarrow \mathrm{H}^{+}+$ $\mathrm{HCO}_{3}{ }^{-} \rightarrow 2 \mathrm{H}^{+}+\mathrm{CO}_{3}{ }^{2-}$. In fluorite and sphalerite grains, these C-type FIs generally coexist with these transparent daughter-bearing S-type FIs. The $\mathrm{CO}_{2}$ melting temperatures $\left(T_{\mathrm{m}-\mathrm{CO} 2}\right)$ range from -57.3 to $-55.8^{\circ} \mathrm{C}$, closer to the triple point for pure $\mathrm{CO}_{2}\left(-56.6^{\circ} \mathrm{C}\right)$. The salinities of C-type FIs in the main stage are estimated to be $0.2-5.6 \mathrm{wt} . \% \mathrm{NaCl}$ equivalent, which are lower than that of C-type FIs in the early stage (6.1-8.3 wt.\% $\mathrm{NaCl}$ equivalent). As a whole, the ore-forming fluids at this stage are characterized by relatively lower temperature (peak temperature between 200 and $240^{\circ} \mathrm{C}$ ) (Figure $10(\mathrm{c})$ ) and salinity (0.5-12.7 wt.\% $\mathrm{NaCl}$ equivalent) (Figure 10(d)) than the early stage. Additionally, a lot of fluorite crystallizing at this stage illustrates that the ore-forming fluids are enriched in $\mathrm{F}^{-}$and belong to an F-rich $\mathrm{NaCl}-\mathrm{H}_{2} \mathrm{O}-\mathrm{CO}_{2}$ system.

In the late stage, as a result of the extremely small size of quartz and carbonate grains, none of FIs has been observed in quartz-carbonate veins. However, abundant secondary Wtype FIs in fluorite and sphalerite have been measured with the features of low temperature $\left(111-174^{\circ} \mathrm{C}\right.$ ) (Figure $10(\mathrm{e})$ ) and low salinity (0.2-8.8 wt.\% $\mathrm{NaCl}$ equivalent) (Figure $10(\mathrm{f})$ ). To a certain extent, petrographic characteristics and compositional types of FIs can be considered to stand for the nature of ore-forming fluids at the late stage [50]. Hence, the ore-forming fluids in the late stage are likely to be characterized by low temperature (Figure 10(e)) and low salinity (Figure 10(f)).

In summary, the ore-forming fluids in the Zhijiadi deposit are characterized by medium-low temperature, low salinity, and an F-rich $\mathrm{NaCl}-\mathrm{H}_{2} \mathrm{O}-\mathrm{CO}_{2}$ system.

6.2. Mineralization Trapping Pressure. The estimation of trapping pressure and mineralization depth are of great significance for targeting of deep-seated blind orebodies and distinguishing deposit type [57]. The existence of abundant C-type and W-type FIs in the Zhijiadi deposit makes it possible to obtain the trapping pressure and mineralization depth $[58,59]$. Isochores of fluid inclusions are defined on the P-T diagram through the Flincor program with the equation proposed by Bowers and Helgeson [42].

In the early stage, C-type FIs from the quartz-pyrite veins were selected for the pressure estimation. The maximum and minimum densities of these C-type FIs are 0.70 and $0.65 \mathrm{~g} / \mathrm{cm}^{3}$, respectively, and they have been completely homogenized into the liquid phase at the temperature of $188-298^{\circ} \mathrm{C}$, with the peak temperature of $280-300^{\circ} \mathrm{C}$. Their peak homogenization temperatures are used to represent the lower limit of fluid temperatures, and these isochores of the C-type FIs imply that the pressure of ore-forming fluids in this stage is approximately 203 to $299 \mathrm{MPa}$ at the temperature of $280-300^{\circ} \mathrm{C}$ (Figure $13(\mathrm{a})$ ).

Abundant W-type and C-type FIs in the fluorite provide a great opportunity to acquire reliable trapping pressure of ore-forming fluids in the main stage. The intersection 
TABLE 4: Lead isotope data of sulfides and rocks from the Zhijiadi Ag-Pb-Zn deposit.

\begin{tabular}{|c|c|c|c|c|c|c|c|c|}
\hline Sample ID & Mineral & ${ }^{206} \mathrm{~Pb} /{ }^{204} \mathrm{~Pb}$ & $2 \sigma$ & ${ }^{207} \mathrm{~Pb} /{ }^{204} \mathrm{~Pb}$ & $2 \sigma$ & ${ }^{208} \mathrm{~Pb} /{ }^{204} \mathrm{~Pb}$ & $2 \sigma$ & Reference \\
\hline Z1320-1 & Galena & 16.5380 & 0.0005 & 15.2641 & 0.0005 & 36.6832 & 0.0014 & This study \\
\hline Z1320-2 & Galena & 16.6921 & 0.0005 & 15.2648 & 0.0006 & 36.9828 & 0.0016 & This study \\
\hline Z1320-3 & Galena & 16.6924 & 0.0004 & 15.2647 & 0.0004 & 36.9886 & 0.0014 & This study \\
\hline Z1320-7 & Galena & 16.6809 & 0.0006 & 15.2656 & 0.0006 & 36.9505 & 0.0014 & This study \\
\hline Z1320-12 & Galena & 16.5373 & 0.0010 & 15.2669 & 0.0009 & 36.6951 & 0.0023 & This study \\
\hline Z1320-18 & Galena & 16.5323 & 0.0008 & 15.2674 & 0.0007 & 36.6736 & 0.0017 & This study \\
\hline Z1360-8 & Galena & 16.5513 & 0.0007 & 15.2636 & 0.0007 & 36.6943 & 0.0017 & This study \\
\hline Z1360-9 & Galena & 16.5604 & 0.0006 & 15.2667 & 0.0006 & 36.7142 & 0.0016 & This study \\
\hline Z1360-9 & Sphalerite & 16.5560 & 0.0004 & 15.2651 & 0.0004 & 36.7065 & 0.0010 & This study \\
\hline Z1360-10 & Galena & 16.6896 & 0.0005 & 15.2634 & 0.0005 & 36.9837 & 0.0012 & This study \\
\hline Z1360-10 & Sphalerite & 16.6984 & 0.0004 & 15.2662 & 0.0004 & 36.9998 & 0.0010 & This study \\
\hline Z1400-2 & Galena & 16.5421 & 0.0004 & 15.2669 & 0.0004 & 36.6780 & 0.0012 & This study \\
\hline Z1400-2 & Sphalerite & 16.5734 & 0.0005 & 15.2712 & 0.0004 & 36.8127 & 0.0011 & This study \\
\hline Z1400-3 & Sphalerite & 16.5384 & 0.0005 & 15.2653 & 0.0005 & 36.6673 & 0.0011 & This study \\
\hline ZK2207-36 & Quartz porphyry & 16.5500 & 0.0006 & 15.2677 & 0.0005 & 36.6623 & 0.0014 & This study \\
\hline ZK2207-94 & Quartz porphyry & 16.5318 & 0.0005 & 15.2631 & 0.0005 & 36.6556 & 0.0013 & This study \\
\hline ZK2207-194 & Quartz porphyry & 16.5141 & 0.0005 & 15.2658 & 0.0004 & 36.6333 & 0.0013 & This study \\
\hline ZK2207-198 & Quartz porphyry & 16.5104 & 0.0005 & 15.2641 & 0.0005 & 36.6289 & 0.0013 & This study \\
\hline Z0617-16a & Quartz porphyry & 16.254 & 0.002 & 15.24 & 0.001 & 36.602 & 0.001 & [35] \\
\hline Z0617-16b & Quartz porphyry & 16.486 & 0.003 & 15.249 & 0.001 & 36.561 & 0.002 & [35] \\
\hline Z0618-8 & Quartz porphyry & 16.804 & 0.002 & 15.313 & 0.001 & 36.99 & 0.001 & [35] \\
\hline Z0618-34 & Quartz porphyry & 16.539 & 0.002 & 15.252 & 0.001 & 36.643 & 0.001 & [35] \\
\hline Z0619-25 & Quartz porphyry & 16.986 & 0.002 & 15.328 & 0.001 & 36.999 & 0.001 & {$[35]$} \\
\hline Z0619-7 & Quartz porphyry & 16.691 & 0.002 & 15.236 & 0.001 & 36.898 & 0.001 & {$[35]$} \\
\hline Z0619-17 & Granite porphyry & 16.623 & 0.002 & 15.232 & 0.001 & 36.721 & 0.001 & [35] \\
\hline
\end{tabular}

TABLe 5: Representative EMPA data (in wt.\%) of sphalerite from the Zhijiadi Ag- $\mathrm{Pb}-\mathrm{Zn}$ deposit.

\begin{tabular}{lccccccccccccc}
\hline Number & Sample ID & Mineral & $\mathrm{Cu}$ & $\mathrm{Ge}$ & $\mathrm{Ga}$ & $\mathrm{Cd}$ & $\mathrm{Pb}$ & $\mathrm{Fe}$ & $\mathrm{Zn}$ & $\mathrm{S}$ & Total & $\mathrm{Zn} / \mathrm{Fe}$ & $\mathrm{Temperature}\left({ }^{\circ} \mathrm{C}\right)$ \\
\hline$(1)$ & $7-1$ & Sphalerite & 0.12 & $\mathrm{bdl}$ & $\mathrm{bdl}$ & $\mathrm{bdl}$ & $\mathrm{bdl}$ & 2.85 & 63.32 & 33.93 & 100.21 & 0.05 & 268 \\
$(2)$ & $7-2$ & Sphalerite & 0.03 & $\mathrm{bdl}$ & 0.05 & 0.45 & $\mathrm{bdl}$ & 2.80 & 63.60 & 33.48 & 100.41 & 0.05 & 267 \\
$(3)$ & $7-3$ & Sphalerite & 0.04 & 0.01 & $\mathrm{bdl}$ & $\mathrm{bdl}$ & 0.02 & 3.34 & 62.77 & 33.58 & 99.76 & 0.06 & 275 \\
$(4)$ & $7-4$ & Sphalerite & 0.06 & $\mathrm{bdl}$ & $\mathrm{bdl}$ & $\mathrm{bdl}$ & 0.04 & 1.86 & 64.31 & 33.45 & 99.72 & 0.03 & 253 \\
$(5)$ & $7-5$ & Sphalerite & 0.14 & $\mathrm{bdl}$ & $\mathrm{bdl}$ & $\mathrm{bdl}$ & $\mathrm{bdl}$ & 2.62 & 63.35 & 33.19 & 99.30 & 0.05 & 264 \\
$(6)$ & $7-6$ & Sphalerite & 0.03 & $\mathrm{bdl}$ & $\mathrm{bdl}$ & 0.57 & $\mathrm{bdl}$ & 0.67 & 66.20 & 33.86 & 101.33 & 0.01 & 236 \\
$(7)$ & $7-7$ & Sphalerite & $\mathrm{bdl}$ & 0.027 & $\mathrm{bdl}$ & $\mathrm{bdl}$ & $\mathrm{bdl}$ & 1.67 & 65.33 & 33.62 & 100.65 & 0.03 & 250 \\
$(8)$ & Mean & Sphalerite & 0.07 & 0.0195 & 0.05 & 0.5055 & 0.03 & 2.26 & 64.13 & 33.59 & 100.20 & 0.04 & 259 \\
\hline
\end{tabular}

bdl, below detection limit.

of isochores in different types of inclusions (i.e., $\mathrm{W}$ - and C-type) is one important method for pressure estimation $[41,50,59]$. The maximum and minimum densities of $\mathrm{C}$ type FIs in fluorite are $0.62 \mathrm{~g} / \mathrm{cm}^{3}$ and $0.47 \mathrm{~g} / \mathrm{cm}^{3}$, and those of W-type FIs are $0.91 \mathrm{~g} / \mathrm{cm}^{3}$ and $0.82 \mathrm{~g} / \mathrm{cm}^{3}$, respectively. The trapping pressure based on intersections among the isochores in different types of FIs is from 32 to $158 \mathrm{MPa}$ at the temperature of $210-279^{\circ} \mathrm{C}$ (Figure $13(\mathrm{~b})$ ). This intersection temperature is consistent with the independent temperature calculated from EPMA data of sphalerite $\left(236-275^{\circ} \mathrm{C}\right)$ and/or the sulfur isotope equilibrium temperatures of sphalerite and galena pairs $\left(237-267^{\circ} \mathrm{C}\right)$ within the analytic error. Hence, the initial trapping pressure of ore-forming fluids in the main stage can be obtained to be 32 to $158 \mathrm{MPa}$ at temperature of $210-279^{\circ} \mathrm{C}$.

As is shown in Figure 13(c), there is an obviously downward trend where the trapping pressures drop from 203-299 MPa in the early stage to 32 to $158 \mathrm{MPa}$ in the main stage.

On the basis of the deposit geology and regional geology, the pressure estimated from this study can stand for the pressure evolution of initial ore-forming fluids from the early to main stage by the following reasons: (1) the occurrence of most of orebodies in the Zhijiadi deposit is controlled by the fault $\mathrm{F}_{2}$. The $\mathrm{F}_{2}$ fault belongs to a compression-shear type fault (Figure 4(b)), which suggests that mineralization 


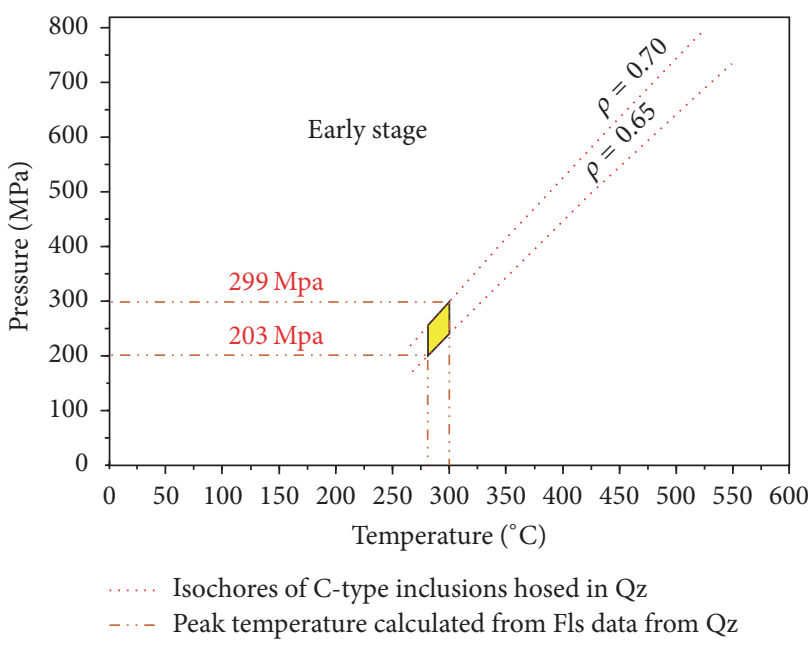

(a)

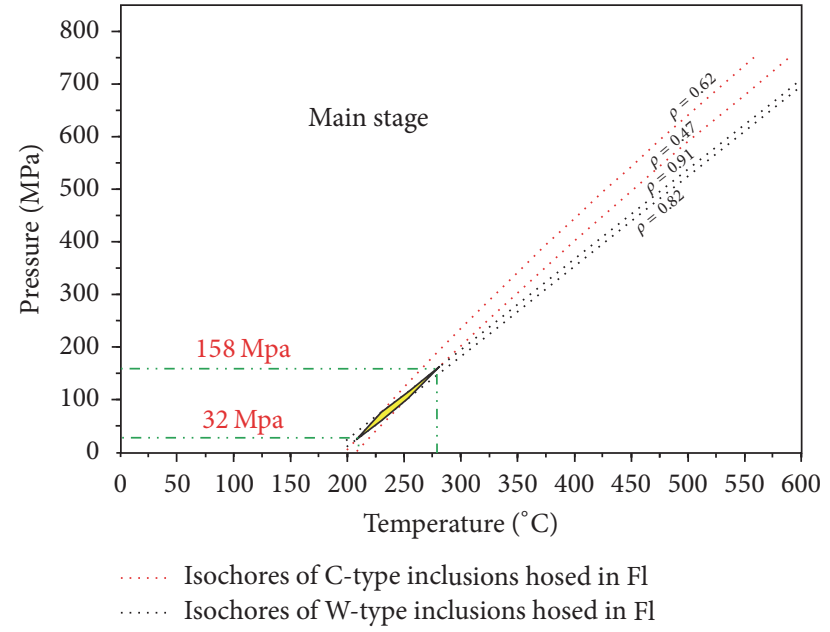

(b)

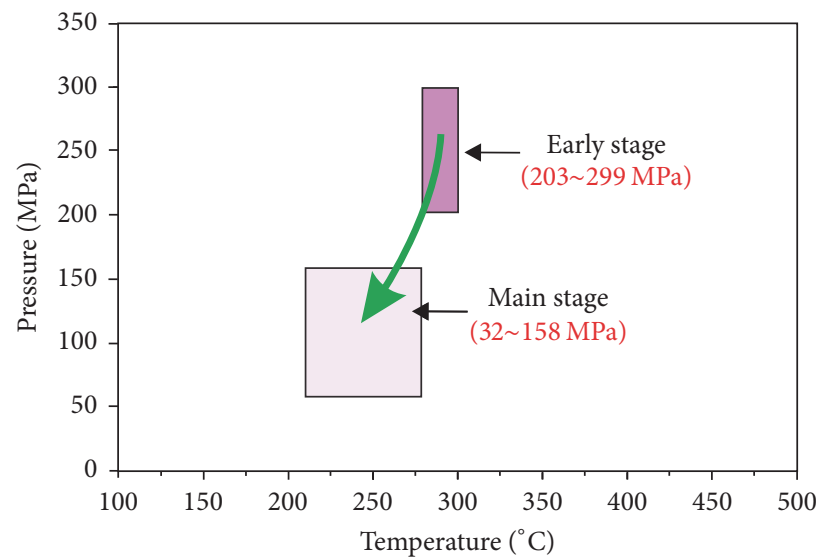

(c)

FIGURE 13: Pressure-temperature conditions for the early and main stages in the Zhijiadi deposit. (a) Minimum trapping pressure for the early stage based on isochores of C-type FIs in the quartz and the peak homogenization temperatures. (b) Trapping pressures for the main stage based on intersections of isochores of the minimum and maximum densities from the C- and W-type FIs in fluorite. (c) Model for pressure-temperature evolution of the ore-forming fluids from the early to main stages. Qz, quartz; Sp, sphalerite; Fl, fluorite.

process in the $\mathrm{F}_{2}$ fault zone was carried out under a relatively sealing condition and high pressure; (2) it is important to note that the early stage quartz veins are typically quite narrow, and the central part of the early stage quartz veins is refilled by the main stage polymetallic sulfides (mainly galena and sphalerite) (Figure 6(a)), which supports the point where there is a tectonic shift from the close system in early stage $(203-299 \mathrm{MPa})$ to the relatively open system in the main stage (32 to $158 \mathrm{MPa}$ ); (3) geologic observations show that hydrothermal breccia, cataclastic rocks, and fault gouge are well developed along the $\mathrm{F}_{2}$ fault zone. This may indicate the existence of multiple deformation events under different structural regimes [60]; (4) in general, the orogenic-type deposits are characterized by the high-content of $\mathrm{CO}_{2}$ (e.g., [24]) and have an obvious decrease from the early high pressure to the late low pressure $[61,62]$. The ore-forming fluids in the Zhijiadi deposit have also characteristics by the existence of abundant $\mathrm{CO}_{2}$; (5) Zhang et al. [17] proposed that the metallogenic timing of the Zhijiadi deposit is considered to be the Late Jurassic to Early Cretaceous. During this period, there existed an obviously tectonic transformation in the Wutai-Hengshan region from the compression to the extension [32], which corresponds to the pressure evolution of ore-forming fluids in the Zhijiadi deposit from the early stage to the main stage. We suggest that such circumstances may be caused by tectonic activity, which means the metallogenic pressure (203-299 MPa in the early stage and 32 to $158 \mathrm{MPa}$ in the main stage) of the Zhijiadi deposit may record the tectonic activities rather than the upper crustal rock conditions. In general, hydrostatic pressure and lithostatic pressure are used to estimate the mineralization depth. Given that $2.7 \mathrm{~g} / \mathrm{cm}^{3}$ is the average density of upper crustal rocks, the pressure of the early and main stages corresponds to the lithostatic depth of $7.5-11.1 \mathrm{~km}$ and $1.2-8.1 \mathrm{~km}$, respectively. However, these estimated depth results do not conform to the geological characteristics that abundant volcanic rocks (e.g., tuff) occurred in the mining area which may be produced at relatively shallow environment. The existence 


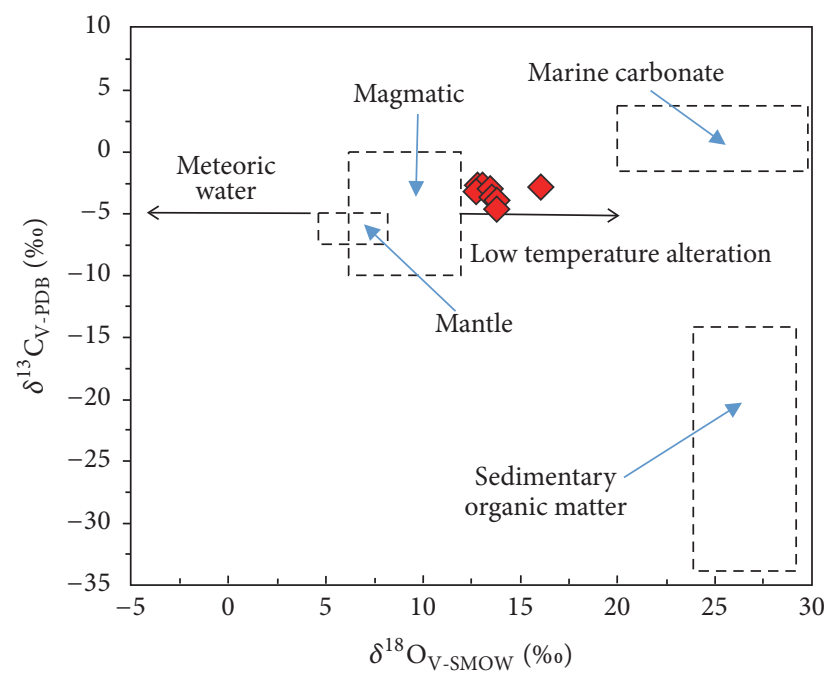

Rhodochrosite

FIgURE 14: $\delta^{18} \mathrm{O}$ versus $\delta^{13} \mathrm{C}$ diagram of rhodochrosite from the Zhijiadi deposit. The base map is from [36, 37].

of multistage breccia in the Zhijiadi deposit indicated that fluid pressure locally exceeded lithostatic pressure [63]. In consideration of early stage quartz-pyrite vein crossed by the main stage galena + sphalerite vein (Figure 6(a)), it may imply that the metallogenetic environment changed from compression (shear) to extension (open) dynamics. As a result, the estimated depth, $7.5-11.1 \mathrm{~km}$ for early stage and $1.2-8.1 \mathrm{~km}$ for main stage, by using $2.7 \mathrm{~g} / \mathrm{cm}^{3}$ as the average density of upper crustal rocks, could not represent the true metallogenic depth.

\subsection{Sources of the Ore-Forming Fluids and Materials}

6.3.1. Source of Ore-Forming Fluids. The C-O isotopic compositions of rhodochrosite from the Zhijiadi deposit suggest that they formed in a magmatic-hydrothermal system. All of their $\delta^{13} \mathrm{C}_{\mathrm{V} \text {-PDB }}$ values $(-2.8$ to $-4.4 \%$ ) are significantly higher than organic material in sedimentary rocks $(-30$ to $-10 \%$ [64]) but are similar to or slightly higher than those of mantle ( -5 to $-7 \%$ [65]) and igneous rocks and magmatic systems ( -3 to $-30 \%$ [65]). Moreover, the plotted data (Figure 14) indicates that $\mathrm{CO}_{2}$ of ore-forming fluids might be main source from a magmatic-hydrothermal system, sharing similar source with the $\mathrm{H}_{2} \mathrm{O}$ in the Zhijiadi deposit [20].

6.3.2. Source of Ore-Forming Materials. Previous studies reported that the sulfur isotopic compositions of sulfides in the Zhijiadi deposit were relatively stable around zero $\left(\delta^{34} S \approx\right.$ $0 \%$ ), demonstrating that sulfur of this deposit was provided by the deep-sourced magmatic system $[14,19,20]$. However, the $\delta^{34} \mathrm{~S}$ values of the sulfides in this study were found to vary in a wide range $(-17.0 \%$ to $+5.5 \%$ ) (Figure 11$)$ by means of in situ sulfur isotope analyses. Compared with the $\delta^{34} \mathrm{~S}$ values of local Early Cretaceous subvolcanic intrusions (quartz porphyry, 2.3\%o to $3.3 \%$ ) and magmatic source $\left(\delta^{34} S=0 \pm 3 \%\right.$ o $\left.[64,66]\right)$, the $S$ isotopic compositions for a majority of sulfides in the Zhijiadi deposit seem to be similar to them despite the slight difference caused by galena at the later main stage. Particularly, the $\delta^{34} S$ values of pyrite $(+0.2 \%$ o to $+5.5 \%$ ) in the early stage, sphalerite $(0 \%$ o to $+3.3 \%$ ) , and chalcopyrite $(+1.1 \%$ o to $+3.0 \%)$ in the main stage yield similar range to magmatic source, whereas the $\delta^{34} S$ values of galena in the latest crystallization of the main stage are the most negative with galena sulfur isotope data fluctuating in a large span from $-17.0 \%$ to $2.9 \%$.

Sakai [67] and Ohmoto [38] proposed that the S isotopic compositions of sulfur minerals that formed in the hydrothermal system are influenced by not only the $\delta^{34} \mathrm{~S}$ value of source materials, but also the physicochemical conditions (temperature, $\mathrm{pH}$ value, oxygen fugacity, and ion activity) of the ore-forming fluids. In general, there are two main probably factors resulting in the negative sulfur isotopic value: (1) biologic processes (e.g., reduction of sulfate to sulfide by sulfur-reducing bacteria during the late stage mineralization and the mixture of biogenic and magmatic sulfur lead to the isotopic values as low as $-17.0 \%$ ); (2) the sharp change of oxygen fugacity from the main stage to the late stage [38]. Firstly, there are not any sulfide-bearing sedimentary rocks or biogenetic texture of these sulfides. Secondly, the C$\mathrm{O}$ isotopic compositions of rhodochrosite also suggest that there is no addition of the sedimentary organic matter into the ore-forming fluids. Therefore, the former explanation for the negative sulfur isotopic values of these sulfides can be excluded. Moreover, previous $\mathrm{H}-\mathrm{O}$ isotopic analyses of the Zhijiadi deposit show that its ore-forming fluids mainly came from magmatic system with a significant input of oxidized meteoric water [20]. Hence, the large variation and negative values in the sulfur isotopic compositions of galena can be interpreted as the shift in oxidation state, which was caused by progressive mixture with oxidized meteoric waters. In general, it can be concluded that the sulfur of the Zhijiadi deposit can be attributed to a magmatic sulfur reservoir with variation caused by the change in oxygen fugacity between these ore stages (Figure 15) [38].

The $\mathrm{Pb}$ isotope compositions of the sulfides from the Zhijiadi deposit show a narrow range, with all data plotted into the area of the Early Cretaceous subvolcanic rocks. The ratios of ${ }^{206} \mathrm{~Pb} /{ }^{204} \mathrm{~Pb},{ }^{207} \mathrm{~Pb} /{ }^{204} \mathrm{~Pb}$, and ${ }^{208} \mathrm{~Pb} /{ }^{204} \mathrm{~Pb}$ for these sulfides vary from 16.5323 to $16.6984,15.2634$ to 15.2712 , and 36.6673 to 36.9998 , respectively. In the ${ }^{207} \mathrm{~Pb} /{ }^{204} \mathrm{~Pb}$ versus ${ }^{206} \mathrm{~Pb} /{ }^{204} \mathrm{~Pb}$ diagram, all of the samples are plotted near to the lower crust line (Figure 12(a)), while the lead isotope data are plotted into the field between the lower crust and orogenic belt evolution lines in the ${ }^{208} \mathrm{~Pb} /{ }^{204} \mathrm{~Pb}$ versus ${ }^{206} \mathrm{~Pb} /{ }^{204} \mathrm{~Pb}$ diagram (Figure 12(b)). This suggests that the sulfides and subvolcanic rocks share the same $\mathrm{Pb}$ source, namely, the lower crust, further demonstrating that the ore-forming materials were of magmatic origin.

6.4. Metallogenic Processes and Ore Genesis. Fluid inclusions are one of the most important sources, which provide critical information on ore-forming process in the hydrothermal 


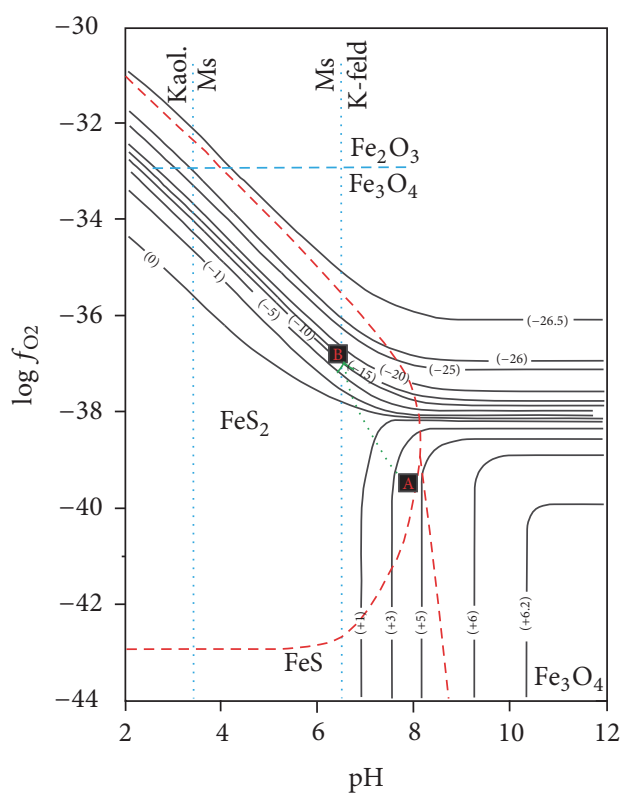

FIGURE 15: $\log f_{\mathrm{O} 2}$ versus $\mathrm{pH}$ isothermal diagram showing stability relationships in the system Fe-O-S for early and main stage (A) and late stage (B) of the paragenesis (modified from [38]). Given Fe$\mathrm{O}-\mathrm{S}$ mineral boundaries at $\Sigma \mathrm{S}=0.1$ moles $/ \mathrm{kg} \mathrm{H}_{2} \mathrm{O}, \mathrm{T}=250^{\circ} \mathrm{C}$, and $I=1.0$ condition, thinner red lines represent the stability field boundaries for pyrite, pyrrhotite, magnetite, and hematite with the following reasons: (1) the sulfur isotopic equilibrium temperatures are estimated to be $237-267^{\circ} \mathrm{C}$; (2) previous study shows that $\mathrm{pH}$ value of the ore-forming fluid is near-neutral $\mathrm{pH}$ [19]; (3) the sericitization occurs in the Zhijiadi deposit. Kaol, kaolinite; Ms, muscovite; K-feld, K-feldspar.

systems (e.g., [68]). In combination with geological characteristics and stable isotope studies, fluid inclusion study can shed light on the evolution of ore-forming fluids and provide useful constraints on the metallogenic process.

In natural systems, metals in an ore-forming fluid are generally found in complexes with aqueous $\mathrm{Cl}^{-}$and $\mathrm{HS}^{-}$and are transported in the form of metal-ligand complexes (e.g., [69]). Temperature is an important factor for the stability of metal complexes and the solubility of ore-forming materials. A certain degree of cooling for the ore-forming fluids could not only destroy the stability of the metal complexes but also reduce the solubility of the ore-forming materials, and it finally causes the precipitation of base metals from the hydrothermal system [70-72]. The fluid evolution diagram for the Zhijiadi deposit, represented by a homogenization temperature versus salinity plot, is shown in Figure 16. There is a clear trend that the homogenization temperature and salinity of the hydrothermal fluids gradually decreased from the early stage, through the main stage, to the late stage.

The trapping pressures that we obtained also share similar variation, dropping from 203-299 MPa to 32-158 MPa during the early and main stages of the hydrothermal process. Therefore, remarkable reduction of pressure could lead to the ascension of the magmatic fluid along fault zones to higher levels, and the magmatic-hydrothermal fluids then were mixed with circulating meteoric water, finally precipitating

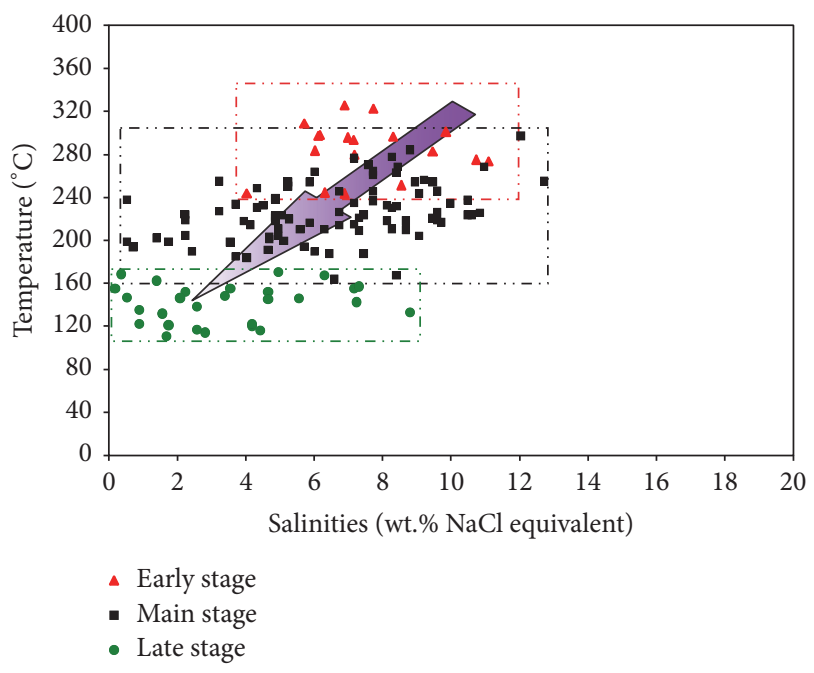

FIGURE 16: Homogenization temperature versus salinity plot of fluid inclusions showing fluid evolution in the Zhijiadi deposit.

sulfides and forming ore deposit (e.g., [63]). Hence, the reduction of pressure has a significant effect on the reduction of temperature and mixing and/or dilution for ore-forming fluids, as well as the formation of ore deposit. Furthermore, previous $\mathrm{H}-\mathrm{O}$ isotopic analyses show that the ore-forming fluids are sourced from a magmatic system with a significant input of meteoric water into it [20]. Progressive input of meteoric water caused the gradual dilution of ore-forming fluid and reduced its temperature and salinity (Figure 15).

A great number of researches were carried on the Zhijiadi deposit, whereas its genesis remains controversial. On the basis of geological characteristics, stable isotopic analysis, and the mineralization temperature, there are two main views that were proposed to interpret its genesis, for example, (1) subvolcanic rock-hosted medium-low temperature hydrothermal deposit [14] and (2) epithermal deposit [17, 73]. However, our new data from the estimation of trapping pressure from fluid inclusions and stable isotope analyses indicated that the Zhijiadi deposit has many differences from typical epithermal deposits.

Up to now, it has been widely accepted that the epithermal deposit generally forms at low temperatures $\left(<300^{\circ} \mathrm{C}\right)$, medium-low salinity fluids, and low content of $\mathrm{CO}_{2}$, with relatively low mineralization pressure [24, 74-76]. However, the microthermometric data in our work suggests that the ore-forming fluids in the Zhijiadi deposit are characterized by medium-low temperature $\left(117-334^{\circ} \mathrm{C}\right)$, low salinity, and abundant $\mathrm{CO}_{2}$. The trapping pressures range from 203-209 MPa in the early stage to $32-158 \mathrm{MPa}$ in the main stage, which are obviously different from the characteristic of epithermal deposits (<10 MPa) (e.g., [76]).

In addition, the $\mathrm{C}-\mathrm{O}-\mathrm{S}$ isotope data indicate that the oreforming fluids and materials are sourced from a magmatic system. The $\mathrm{Pb}$ isotopes further confirm the sulfides and subvolcanic rocks have the same sources, namely, the lower crust, demonstrating that the ore-forming materials were of magmatic origin. 
Furthermore, the occurrence of orebodies in the Zhijiadi deposits are strictly controlled by a series of NW-, EW-, and NE-trending faults, especially for the $\mathrm{F}_{2}$ fault. The hydrothermal alterations associated with $\mathrm{Ag}-\mathrm{Pb}-\mathrm{Zn}$ mineralization in the Zhijiadi deposit are mainly composed of silicification, carbonation, sericitization, and chloritization. The gangue minerals are quartz, rhodochrosite, fluorite, calcite, and dolomite, which are not accordant with the typical characteristics of alternation in epithermal deposits (e.g., adularization or alunitization $[24,76,77]$ ), which can further rule out the possibility that the Zhijiadi deposit is a kind of epithermal deposit. Based on all available geological and geochemical evidence, we propose that the Zhijiadi deposit belongs to medium-low temperature hydrothermal deposit related to volcanic and subvolcanic magmatism strictly controlled by fault zones instead of epithermal deposit.

\section{Conclusions}

(1) The Zhijiadi deposit, located in the central North China Craton, is hosted in volcanic and subvolcanic rocks and fault zones. According to the mineral assemblages and crosscutting relationship, hydrothermal metallogenic processes can be divided into the early stage, the main stage, and the late stage, represented by quartz + pyrite veins, rhodochrosite + fluorite + galena + sphalerite + chalcopyrite + multiple Agbearing sulfides, and quartz + carbonate veins.

(2) The fluid inclusions of the Zhijiadi deposit are primarily aqueous (W-type), aqueous-carbonate (C-type), and daughter mineral-bearing (S-type) inclusions. Marcasite is recognized as the daughter minerals in the early stage quartzpyrite vein, whereas chalcopyrite, calcite, and dolomite occur as daughter minerals in the main stage fluorite and sphalerite. The ore-forming fluids are characterized by medium-low temperature, low salinity, and abundant $\mathrm{CO}_{2}$ and belong to an F-rich $\mathrm{H}_{2} \mathrm{O}-\mathrm{NaCl}-\mathrm{CO}_{2}$ system. From the early, through the main, to the late stage, the homogenization temperatures and salinities of the hydrothermal fluids gradually decrease.

(3) The C-O isotopic compositions indicate that the oreforming fluids of the Zhijiadi deposit were sourced from a magmatic system in origin. Analyses of $S$ isotopes suggest that the sulfur of Zhijiadi deposit was attributed to the magmatic sulfur reservoir with variation caused by the change in oxygen fugacity. The $\mathrm{Pb}$ isotopes further confirm the sulfides and subvolcanic rocks share the same sources, namely, the lower crust.

(4) The Zhijiadi deposit belongs to medium-low temperature hydrothermal deposit strictly controlled by the fault zones. There is an obviously downward trend that the trapping pressures of ore-forming fluids in the Zhijiadi deposit drop from 203-299 MPa in the early stage to 32 to $158 \mathrm{MPa}$ in the main stage. The reduction of pressure has a significant effect on the reduction of temperature, mixing, and/or dilution for ore-forming fluids, as well as the formation of ore deposit.

\section{Conflicts of Interest}

The authors declare that they have no conflicts of interest.

\section{Acknowledgments}

The authors thank Zhi Yuan-Dong and Ma Ying for providing support in the field work. They also thank Drs. Zhao KuiDong, He Mou-Chun, Xu Yao-Ming, Jiang Man-Rong, Zhang $\mathrm{Di}$, and Zhu Zi-Yi for their help with the lab work. This work was financially supported by the National Key R\&D Program of China (no. 2017YFC0601404) and China Geological Survey Project (no. 12120115036801).

\section{References}

[1] G. Zhao and M. Zhai, "Lithotectonic elements of Precambrian basement in the North China Craton: review and tectonic implications," Gondwana Research, vol. 23, no. 4, pp. 1207-1240, 2013.

[2] T. M. Kusky and J. Li, "Paleoproterozoic tectonic evolution of the North China Craton," Journal of Asian Earth Sciences, vol. 22, no. 4, pp. 383-397, 2003.

[3] M. Zhai, J. Guo, and W. Liu, "Neoarchean to Paleoproterozoic continental evolution and tectonic history of the North China Craton: A review," Journal of Asian Earth Sciences, vol. 24, no. 5, pp. 547-561, 2005.

[4] M. Faure, P. Trap, W. Lin, P. Monié, and O. Bruguier, "Polyorogenic evolution of the Paleoproterozoic Trans-North China Belt-new insights from the Lüliangshan-Hengshan-Wutaishan and Fuping massifs," Episodes, vol. 30, no. 2, pp. 96-107, 2007.

[5] P. Trap, M. Faure, W. Lin, P. Monié, S. Meffre, and J. Melleton, "The Zanhuang Massif, the second and eastern suture zone of the Paleoproterozoic Trans-North China Orogen," Precambrian Research, vol. 172, no. 1-2, pp. 80-98, 2009.

[6] Z. Wang, "Tectonic evolution of the Hengshan-Wutai-Fuping complexes and its implication for the Trans-North China Orogen," Precambrian Research, vol. 170, no. 1-2, pp. 73-87, 2009.

[7] M. Zhai, J. Yang, H. Fan, L. Miao, and Y. Li, "A large-scale cluster of gold deposits and metallogenesis in the eastern North China craton," International Geology Review, vol. 44, no. 5, pp. 458476, 2002.

[8] Z.-K. Li, J.-W. Li, X.-F. Zhao et al., "Crustal-extension Ag$\mathrm{Pb}-\mathrm{Zn}$ veins in the Xiong'ershan District, Southern North China Craton: Constraints from the Shagou deposit," Economic Geology, vol. 108, no. 7, pp. 1703-1729, 2013.

[9] S.-R. Li, M. Santosh, H.-F. Zhang et al., "Metallogeny in response to lithospheric thinning and craton destruction: geochemistry and U-Pb zircon chronology of the Yixingzhai gold deposit, central North China Craton," Ore Geology Reviews, vol. 56, pp. 457-471, 2014.

[10] S. D. Niu, S. R. Li, J. Q. Zhang, and Z. H. Wang, "Characteristics of fluid inclusions and fluid evolution of the Diaoquan Ag-Cu deposit, Lingqiu County, Shanxi Province, North China," Acta Petrologica Sinica, vol. 30, no. 11, pp. 3432-3442, 2014 (Chinese).

[11] H. Q. Zhang, J. B. Wang, and Y. W. Wang, "A study on lithofacies zonation of crypto-explosive breccia pipe in Zhijiadi $\mathrm{Pb}-\mathrm{Zn}-\mathrm{Ag}$ Deposit, Lingqiu County, northeastern Shanxi Province, and its exploration significance," Geological Review, vol. 58, 2012 (Chinese).

[12] J.-Q. Zhang, S.-R. Li, M. Santosh et al., "Timing and origin of Mesozoic magmatism and metallogeny in the Wutai-Hengshan region: Implications for destruction of the North China Craton," Journal of Asian Earth Sciences, vol. 113, pp. 677-694, 2015 (Chinese). 
[13] S. C. Li and L. X. Zhou, "Geology and ore prospecting of Zhijiadi silver deposit in the Lingqiu County, Shanxi," Geology and Prospecting, vol. 44, no. 3, pp. 18-21, 2008 (Chinese).

[14] B. T. Zhang, Z. X. Li, F. Q. Liu, and W. Z. Ma, "Geological characteristics of Zhijiadi silver deposit in Lingqiu, Shanxi," Journal of Geology and Mineral Resources of North China, vol. 10, pp. 257-268, 1995 (Chinese).

[15] Y. Q. Pan and Y. H. Kang, "On the geological characteristics of Zhijadi lead-zinc-silver deposit in Shanxi," Shanxi Architecture, vol. 14, p. 75, 2009 (Chinese).

[16] B. Y. Li and Q. C. Meng, "The geological characteristics and the deep prospecting of Zhijiadi Pb-Zn-Ag deposit," Mineral Deposits, vol. 29, pp. 213-214, 2010 (Chinese).

[17] H. Zhang, J. Wang, Y. Wang, T. Zou, and L. Long, "Zircon $\mathrm{U}-\mathrm{Pb}$ geochronology of the volcanic-subvolcanic rocks and its geological implications on the Zhijiadi silver polymetallic mineralization," Geotectonica et Metallogenia, vol. 40, no. 3, pp. 478-490, 2016 (Chinese).

[18] S. X. Qin, Q. H. Wu, and H. L. Yu, "Microstructure and Geochemical Characteristics of the Ores from the Zhijiadi PbZn-Ag Deposit, Shanxi Province," Geotectonica Et Metallogenia, vol. 35, pp. 118-127, 2011 (Chinese).

[19] Z. L. Li, L. Y. Zhang, and B. H. Fan, "Geological characteristics and genesis of the Zhijiadi silver deposit, Shanxin Province," Mineral Deposits, vol. 11, no. 4, pp. 315-324, 1992 (Chinese).

[20] W. L. Li, R. Xia, M. Qing, and L. Wang, "The H-O-S isotopic characteristics of ore-forming fluid in the Zhijiadi Ag- $\mathrm{Pb}-\mathrm{Zn}$ deposit, Shanxi Province," Mineral Deposits, vol. 31, pp. 565-566, 2012 (Chinese).

[21] Z. P. Feng, "Geochemical characteristics and genetic studies of Zhijiadi silver deposits at Lingqiu County," Shanxi Metallurgy, pp. 18-21, 2010 (Chinese).

[22] M. Y. He and L. Yang, "Characters of the inclusions in Zhijiadi $\mathrm{Ag}-\mathrm{Pb}-\mathrm{Zn}$ deposit, and the origin of their hydrothermal solution," Southern Metals, pp. 9-12, 2011 (Chinese).

[23] L. Wang, L. Q. Jia, W. L. Li, X. D. Guo, and C. Y. Guo, "Geological characteristics and fluid inclusion characteristics of the Zhijiad Ag-Pb-Zn deposit," Bulletin of Mineralogy, Petrology and Geochemistry, vol. 30, pp. 166-167, 2011 (Chinese).

[24] Y. J. Chen, P. Ni, H. R. Fan et al., "Diagnostic fluid inclusions of different types hydrothermal gold deposits," Acta Petrologica Sinca, vol. 23, pp. 2085-2108, 2007 (Chinese).

[25] G. Chi and C. Xue, "Abundance of $\mathrm{CO}_{2}$-rich fluid inclusions in a sedimentary basin-hosted $\mathrm{Cu}$ deposit at Jinman, Yunnan, China: implications for mineralization environment and classification of the deposit," Mineralium Deposita, vol. 46, no. 4, pp. 365-380, 2011.

[26] G. Zhao, P. Cawood, and L. Lu, "Petrology and P-T history of the Wutai amphibolites: Implications for tectonic evolution of the Wutai Complex, China," Precambrian Research, vol. 93, no. 2-3, pp. 181-199, 1999.

[27] J. Bai, "The Precambrian crustal evolution of the Wutaishan area," in The Early Precambrian Geology of Wutaishan, J. Bai, Ed., pp. 376-383, Tianjin Science and Technology Press, Tianjin, China, 1986 (Chinese).

[28] Y. Q. Tian, Y. F. Liang, S. K. Fan, B. Q. Zhu, and Y. W. Chen, "Geochronology of the Hengshan Complex in special reference to Nd isotope evolution," Geochimica, vol. 3, pp. 255-264, 1992, in Chinese.

[29] S. Liu, G. Zhao, S. A. Wilde et al., "Th-U-Pb monazite geochronology of the Lüliang and Wutai Complexes: Constraints on the tectonothermal evolution of the Trans-North
China Orogen," Precambrian Research, vol. 148, no. 3-4, pp. 205224, 2006.

[30] Y. Wang, W. Fan, Y. Zhang, F. Guo, H. Zhang, and T. Peng, "Geochemical, ${ }^{40} \mathrm{Ar} /{ }^{39} \mathrm{Ar}$ geochronological and Sr-Nd isotopic constraints on the origin of Paleoproterozoic mafic dikes from the southern Taihang Mountains and implications for the ca. $1800 \mathrm{Ma}$ event of the North China Craton," Precambrian Research, vol. 135, no. 1-2, pp. 55-77, 2004.

[31] J. Y. Luo, Genetic mineralogy and metallogenic prognosis of Yixingzhai gold deposit in Fan Shi County, Shanxi Province [Ph.D. dissertation], China University of Geosciences, Beijing, China, 2009 (Chinese), http://cdmd.cnki.com.cn/article/cdmd-114152009075393.htm.

[32] C. H. Zhang, C. M. Li, H. L. Deng et al., "Mesozoic contraction deformation in the Yanshan and northern Taihang mountains and its implications to the destruction of the North China Craton," Science China Earth Sciences, vol. 54, no. 6, pp. 798822, 2011 (Chinese).

[33] G. Zhao, P. A. Cawood, S. A. Wilde, M. Sun, and L. Lu, "Metamorphism of basement rocks in the Central Zone of the North China Craton: Implications for paleoproterozoic tectonic evolution," Precambrian Research, vol. 103, no. 1-2, pp. 55-88, 2000.

[34] R. E. Zartman and B. R. Doe, "Plumbotectonics: the model," Tectonophysics, vol. 75, no. 1-2, pp. 135-162, 1981.

[35] H. Q. Zhang, Research on metallization of Zhjiadi epithermaltype Ag-Pb-Zn deposit in Shanxi, China [Ph.D. dissertation], China University of Geosciences, Beijing, China, 2014 (Chinese), http://cdmd.cnki.com.cn/article/cdmd-114151015518049.htm.

[36] J. Liu, M. Zheng, N. J. Cook, X. Long, J. Deng, and Y. Zhai, “Geological and geochemical characteristics of the Sawayaerdun gold deposit, southwestern Chinese Tianshan," Ore Geology Reviews, vol. 32, no. 1-2, pp. 125-156, 2007.

[37] J. M. Liu and J. J. Liu, "Basinal fluid genetic model of fine disseminated gold deposit in the Golden Triangle area between Yunnan, Guizhou and Guangxi," Acta Mineralogica Sinica, vol. 17, pp. 448-456, 1997 (Chinese).

[38] H. Ohmoto, "Systematics of sulfur and carbon isotopes in hydrothermal ore deposits," Economic Geology, vol. 67, no. 5, pp. 551-578, 1972.

[39] H.-J. Peng, J.-W. Mao, L. Hou et al., "Stable isotope and fluid inclusion constraints on the source and evolution of ore fluids in the Hongniu-Hongshan Cu skarn deposit, Yunnan Province, China," Economic Geology, vol. 111, no. 6, pp. 1369-1396, 2016.

[40] D. L. Hall, S. M. Sterner, and R. J. Bodnar, "Freezing point depression of $\mathrm{NaCl}-\mathrm{KCl}-\mathrm{H} 2 \mathrm{O}$ solutions," Economic Geology, vol. 83, no. 1, pp. 197-202, 1988.

[41] E. Roedder, "Fluid inclusions. Reviews in mineralogy," Mineralogical Society of America, vol. 12, p. 644, 1984.

[42] T. S. Bowers and H. C. Helgeson, "Calculation of the thermodynamic and geochemical consequences of nonideal mixing in the system $\mathrm{H}_{2} \mathrm{O}-\mathrm{CO}_{2}-\mathrm{NaCl}$ on phase relations in geologic systems: Equation of state for $\mathrm{H}_{2} \mathrm{O}-\mathrm{CO}_{2}-\mathrm{NaCl}$ fluids at high pressures and temperatures," Geochimica et Cosmochimica Acta, vol. 47, no. 7, pp. 1247-1275, 1983.

[43] I. Friedmanand and J. R. O’Neil, "Compilation of stable isotope fractionation factors of geochemical interest," in Data of Geochemistry, M. Fleischer, Ed., pp. KK1-KK12, United States Government Printing Office, Washington, DC, USA, 6th edition, 1977. 
[44] S. F. Thornton, K. M. Baker, S. H. Bottrell et al., "Enhancement of in situ biodegradation of organic compounds in groundwater by targeted pump and treat intervention," Applied Geochemistry, vol. 48, pp. 28-40, 2014.

[45] Z.-Y. Zhu, S.-Y. Jiang, C. L. Ciobanu, T. Yang, and N. J. Cook, "Sulfur isotope fractionation in pyrite during laser ablation: Implications for laser ablation multiple collector inductively coupled plasma mass spectrometry mapping," Chemical Geology, vol. 450, pp. 223-234, 2017.

[46] Z.-Y. Zhu, N. J. Cook, T. Yang, C. L. Ciobanu, K.-D. Zhao, and S.-Y. Jiang, "Mapping of sulfur isotopes and trace elements in sulfides by LA-(MC)-ICP-MS: potential analytical problems, improvements and implications," Minerals, vol. 6, no. 4, article 110, 2016.

[47] K.-D. Zhao, S.-Y. Jiang, P. Ni, H.-F. Ling, and Y.-H. Jiang, "Sulfur, lead and helium isotopic compositions of sulfide minerals from the Dachang Sn-polymetallic ore district in South China: Implication for ore genesis," Mineralogy and Petrology, vol. 89, no. 3-4, pp. 251-273, 2007.

[48] R.-X. Zhang and S.-Y. Yang, "A mathematical model for determining carbon coating thickness and its application in electron probe microanalysis," Microscopy and Microanalysis, vol. 22, no. 6, pp. 1374-1380, 2016.

[49] M. Keith, K. M. Haase, U. Schwarz-Schampera, R. Klemd, S. Petersen, and W. Bach, "Effects of temperature, sulfur, and oxygen fugacity on the composition of sphalerite from submarine hydrothermal vents," Geology, vol. 42, no. 8, pp. 699702, 2014.

[50] H. Z. Lu, H. R. Fan, P. Ni, G. X. Ou, K. Shen, and W. H. Zhang, Fluid Inclusion, Science Press, Beijing, China, 2004.

[51] H. Ohmoto and R. O. Rye, "Isotopes of sulfur and carbon," Geochemistry of Hydrothermal Ore Deposits, pp. 509-567, 1979.

[52] T. Baker, "Emplacement depth and carbon dioxide-rich fluid inclusions in intrusion-related gold deposits," Economic Geology, vol. 97, no. 5, pp. 1111-1117, 2002.

[53] D. I. Groves, R. J. Goldfarb, F. Robert, and C. J. R. Hart, "Gold deposits in metamorphic belts: Overview of current understanding, outstanding problems, future research, and exploration significance," Economic Geology, vol. 98, no. 1, pp. $1-29,2003$.

[54] J. Lai and G. Chi, " $\mathrm{CO}_{2}$-rich fluid inclusions with chalcopyrite daughter mineral from the Fenghuangshan $\mathrm{Cu}-\mathrm{Fe}-\mathrm{Au}$ deposit, China: implications for metal transport in vapor," Mineralium Deposita, vol. 42, no. 3, pp. 293-299, 2007.

[55] G. N. Phillips and K. A. Evans, "Role of $\mathrm{CO}_{2}$ in the formation of gold deposits," Nature, vol. 429, no. 6994, pp. 860-863, 2004.

[56] H. Z. Lu, "Role of $\mathrm{CO}_{2}$ fluid in the formation of gold deposits: fluid inclusion evidences," Geochimica, vol. 37, pp. 321-328, 2008.

[57] J. Zhong, Y.-J. Chen, F. Pirajno et al., “Geology, geochronology, fluid inclusion and $\mathrm{H}-\mathrm{O}$ isotope geochemistry of the Luoboling porphyry Cu-Mo deposit, Zijinshan Orefield, Fujian Province, China," Ore Geology Reviews, vol. 57, pp. 61-77, 2014.

[58] Y.-F. Yang, N. Li, and Y.-J. Chen, "Fluid inclusion study of the Nannihu giant porphyry Mo-W deposit, Henan Province, China: implications for the nature of porphyry ore-fluid systems formed in a continental collision setting," Ore Geology Reviews, vol. 46, pp. 83-94, 2012.

[59] S. Xiong, M. He, S. Yao et al., "Fluid evolution of the Chalukou giant Mo deposit in the northern Great Xing'an Range, NE China," Geological Journal, vol. 50, no. 6, pp. 720-738, 2015.
[60] X. Cao, S. Li, L. Xu et al., "Mesozoic-Cenozoic evolution and mechanism of tectonic geomorphology in the central North China Block: constraint from apatite fission track thermochronology," Journal of Asian Earth Sciences, vol. 114, pp. 4153, 2015.

[61] L. Zhang, H. Chen, Y. Chen et al., "Geology and fluid evolution of the Wangfeng orogenic-type gold deposit, Western Tian Shan, China," Ore Geology Reviews, vol. 49, pp. 85-95, 2012.

[62] P. Chai, J.-G. Sun, Z.-Q. Hou, S.-W. Xing, and Z.-Y. Wang, "Geological, fluid inclusion, $\mathrm{H}-\mathrm{O}-\mathrm{S}-\mathrm{Pb}$ isotope, and $\mathrm{Ar}-\mathrm{Ar}$ geochronology constraints on the genesis of the Nancha gold deposit, southern Jilin Province, northeast China," Ore Geology Reviews, vol. 72, pp. 1053-1071, 2016.

[63] H. Kouhestani, M. Ghaderi, Z. Chang, and K. Zaw, "Constraints on the ore fluids in the Chah Zard breccia-hosted epithermal au-ag deposit, Iran: fluid inclusions and stable isotope studies," Ore Geology Reviews, vol. 65, no. 2, pp. 512-521, 2015.

[64] G. Faure, Principles of Isotope Geology, John Wiley and Sons, New York, NY, USA, 2nd edition, 1986.

[65] J. Hoefs, Stable Isotope Geochemistry, Springer, Heidelberg, Germany, 4th edition, 2009.

[66] M. Chaussidon and J.-P. Lorand, "Sulphur isotope composition of orogenic spinel lherzolite massifs from Ariege (NorthEastern Pyrenees, France): an ion microprobe study," Geochimica et Cosmochimica Acta, vol. 54, no. 10, pp. 2835-2846, 1990.

[67] H. Sakai, "Isotopic properties of sulfur compounds in hydrothermal processes," Geochemical Journal, vol. 2, no. 1, pp. 29-49, 1968.

[68] J. J. Wilkinson, "Fluid inclusions in hydrothermal ore deposits," Lithos, vol. 55, no. 1-4, pp. 229-272, 2001.

[69] H. L. Barnes, "Solubilities of ore minerals," in Geochemistry of Hydrothermal Ore Deposits, H. L. Barnes, Ed., pp. 404-460, Wiley, New York, NY, USA, 1979.

[70] D. A. Crerar and H. L. Barnes, "Ore solution chemistry $\mathrm{v}$ solubilities of chalcopyrite and chalcocite assemblages in hydrothermal solution at $200^{\circ} \mathrm{C}$ to $350^{\circ} \mathrm{C}$," Economic Geology, vol. 71, no. 4, pp. 772-794, 1976.

[71] G. H. Brimhall and D. A. Crerar, "Ore fluids: magmatic to supergene," in Reviews in Mineralogy and Geochenistry, vol. 17, pp. 235-321, 1987.

[72] T. Li, G. Wu, J. Liu et al., "Geochronology, fluid inclusions and isotopic characteristics of the Chaganbulagen $\mathrm{Pb}-\mathrm{Zn}-\mathrm{Ag}$ deposit, Inner Mongolia, China," Lithos, vol. 261, pp. 340-355, 2016.

[73] J. G. Yang, "Metallogenic features and genesis of the Zhijiadi silver deposit in northeastern Shanxi," Geological Exploration for Non-ferrous Metals, vol. 8, pp. 551-555, 1999 (Chinese).

[74] W. Lindgren, Mineral Deposit, McGraw-Hill, New York, NY, USA, 4th edition, 1993.

[75] H. F. Bonham, "Models for volcanic-hosted epithermal precious metal deposit: a review," in Proceedings of the International Volcanological Congress, Symposium 5, pp. 13-17, Hamiltion, New Zealand, 1986.

[76] P. Heald, N. K. Foley, and D. O. Hayba, "Comparative anatomy of volcanic-hosted epithermal deposits: acid- sulfate and adularia- sericite types.", Economic Geology, vol. 82, no. 1, pp. 1-26, 1987.

[77] J. W. Mao, X. F. Li, Z. H. Zhang, Y. T. Wang, H. M. Li, and H. B. $\mathrm{Hu}$, "Geology, distribution, type and tectonic setting of Mesozoic epithermal gold deposits in East China," Geological Journal of China Universities, vol. 9, pp. 620-637, 2003 (Chinese). 

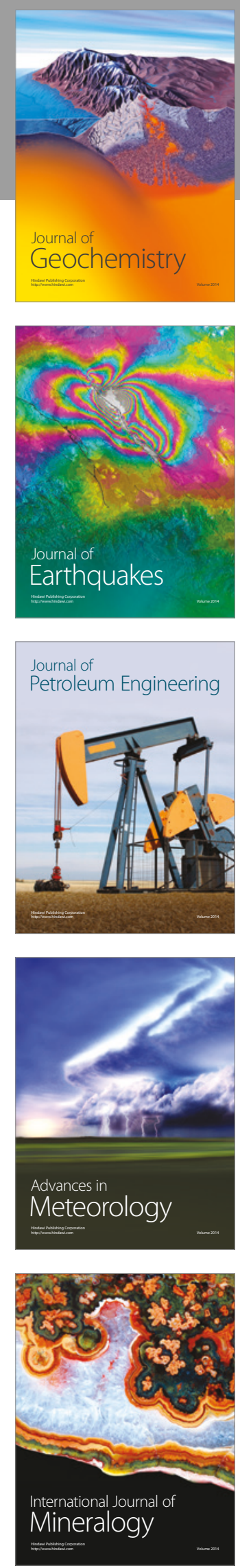
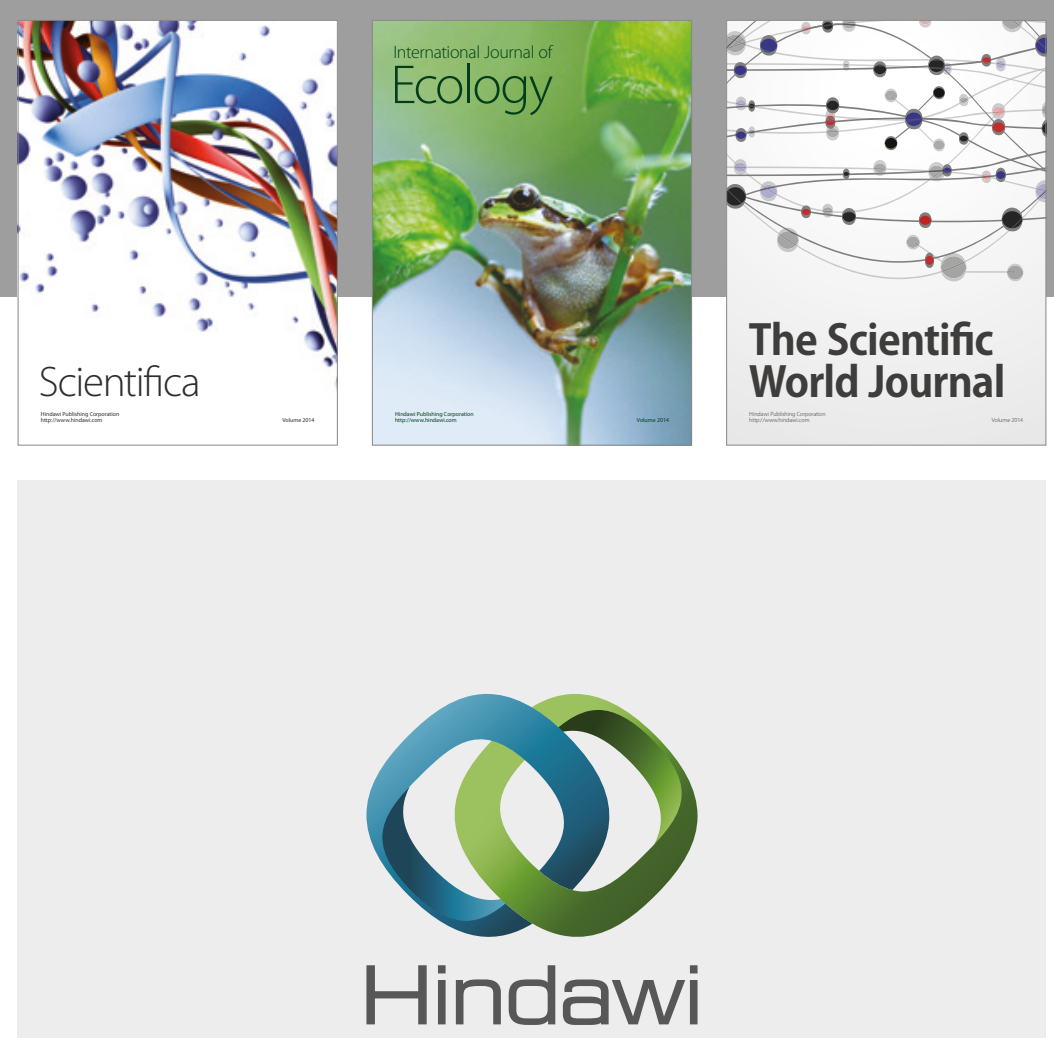

Submit your manuscripts at

https://www.hindawi.com
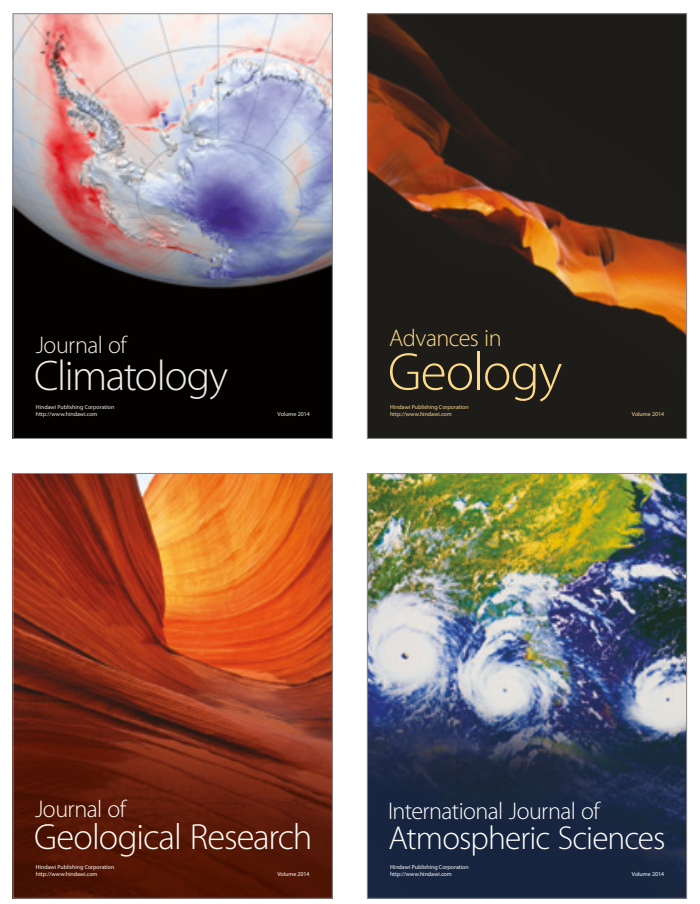

The Scientific

World Journal
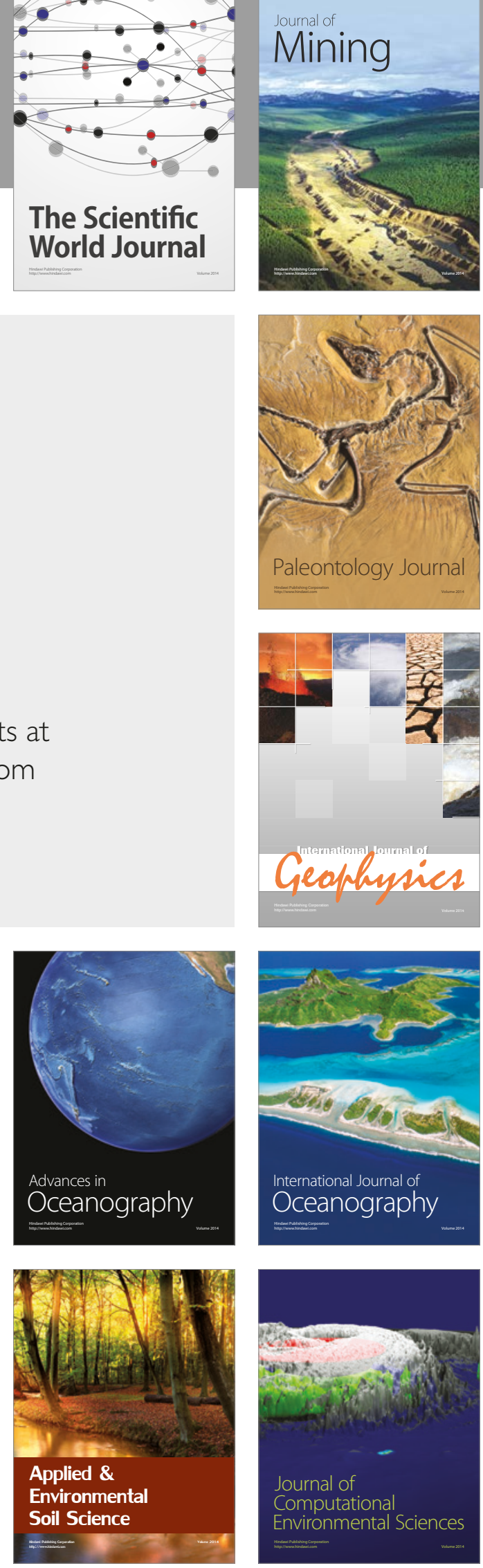